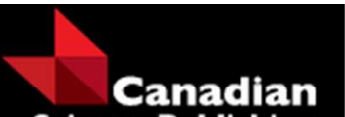

Science Publishing

Canadian Journal of Forest Research

Revue canadienne de recherche forestière

\title{
Carbon and nitrogen stocks in Norwegian forest soils - the importance of soil formation, climate and vegetation type for organic matter accumulation
}

\begin{tabular}{|r|l|}
\hline Journal: & Canadian Journal of Forest Research \\
\hline Manuscript ID & cjfr-2015-0467.R1 \\
\hline Manuscript Type: & Article \\
\hline Complete List of Authors: & $\begin{array}{l}\text { Strand, Line; Norwegian University of Life Sciences, Environmental } \\
\text { Sciences } \\
\text { Callesen, Ingeborg; University of Copenhagen, Department of Geosciences } \\
\text { and Natural Resource Management; } \\
\text { Dalsgaard, Lise; Norwegian Institute of Bioeconomy Research, } \\
\text { de Wit, Heleen; Norwegian Institute for Water Research }\end{array}$ \\
\hline Keyword: & \begin{tabular}{l} 
Forest soil, carbon, soil formation, pedology, boreal forest \\
\hline
\end{tabular} \\
\hline
\end{tabular}

\section{SCHOLARONE \\ Manuscripts}




\section{Carbon and nitrogen stocks in Norwegian forest soils - the importance of soil formation, climate and vegetation type for organic matter accumulation} Line Tau Strand ${ }^{1^{*}}$ Ingeborg Callesen ${ }^{2}$, Lise Dalsgaard ${ }^{3}$ and Heleen A. de Wit $^{4}$

$7{ }^{1}$ Department of Environmental Sciences, Norwegian University of Life Sciences, Post box 5003, N-

81432 Ås, Norway (line.strand@nmbu.no)

92 Department of Geosciences and Natural Resource Management, University of Copenhagen,

10 Rolighedsvej 23, 1958 Frederiksberg C (ica@ign.ku.dk)

$11{ }^{3}$ Norwegian Institute of Bioeconomy Research (NIBIO), Box 115, 1431 Ås, Norway

12 (lise.dalsgaard@nibio.no)

$13{ }^{4}$ Norwegian Institute for Water Research (NIVA), Gaustadalléen 21, 0349 Oslo, Norway

14 (heleen.de.wit@niva.no)

* Corresponding author Line Tau Strand, Department of Environmental Sciences, Norwegian author (+47 67231862) 


\section{Abstract}

25 Relationships between soil $\mathrm{C}$ and $\mathrm{N}$ stocks and soil formation, climate and vegetation were 26 investigated in a gridded database connected to the national forest inventory in Norway. For mineral 27 soil orders $\mathrm{C}$ and $\mathrm{N}$ stocks were estimated to $11.1-19.3 \mathrm{~kg} \mathrm{Cm}^{-2}$ and $0.41-0.78 \mathrm{~kg} \mathrm{Nm}^{-2}$ declining in 28 following order Gleysolic>Podzolic>Brunisolic>Regosolic. Organic-peat type soils stored on average $2931.3 \mathrm{~kg} \mathrm{Cm}^{-2}$ and $1.10 \mathrm{~kg} \mathrm{Nm}^{-2}$, while shallow Organic Folisols, on average stored $10.2 \mathrm{~kg} \mathrm{Cm}^{-2}$ and $30 \quad 0.34 \mathrm{~kg} \mathrm{Nm}^{-2}$. For Norway's $120000 \mathrm{~km}^{-2}$ of forest the total soil C stocks was estimated to $1.83 \mathrm{GtC}$ 31 with CL95\% 1.71-1.95 Gt C. Podzolic soils comprise the largest soil group and they store 32 approximately $50 \%$ of the forest soil C. Sixty percent of the soil C stock in Podzolic soils was stored in 33 the mineral soil, and increase with temperature and precipitation. Poorly drained soil types store 34 approximately $47 \%$ of the total forest soil C in Norway. Soils with water saturation have large C stocks mainly in the forest floor suggesting that they are more susceptible to forest management and environmental change. Soil $\mathrm{C}$ stocks under pine and spruce forest were similar, though pine had larger $\mathrm{C}$ stocks in the forest floor while spruce had the highest $\mathrm{C}$ stocks in the mineral soil compartment. C stocks in forest floor increase from dry to moist ground vegetation, while ground vegetation nutrient classes reflect $\mathrm{C}$ and $\mathrm{N}$ stocks in the mineral soil better. 
Boreal forests are an important part of the global carbon (C) cycle and are considered to be

moderate to strong sinks for atmospheric $\mathrm{C}$, depending on forest management, forest fire, site fertility and local climate e.g. (de Wit et al. 2015; Karhu et al. 2011; Liski et al. 2002; Luyssaert et al. 2010; Schimel et al. 2001; Schulze et al. 1999). The contribution of the soil to the total forest C balance is uncertain, partly because of a general lack of representative forest soil data, as comprehensive soil monitoring is only rarely included in forest inventory programs ( $\underline{\text { Callesen et al. }}$ 2015; Goodale et al. 2002; Van Cleve and Powers 1995). The uncertainty and lack of data on soil contrast with its importance as a C pool. Boreal forest soils including the forest floor have been reported to store two to five times that of the forest biomass (Bradshaw and Warkentin 2015; Goodale et al. 2002) and the organic matter of boreal forest soils is more sensitive to warming than soils of other climatic zones (Davidson and Janssens 2006). Our ability to predict consequences of future climate changes depend in part on our understanding of the distribution and controls of $C$ stocks in soils (Deluca and Boisvenue 2012). Several studies have explored the possibility of using soil inventories and taxonomic units to estimate soil organic C stocks e.g. (Grossman et al. 2001; Guo et al. 2006; Shaw et al. 2008; Tarnocai 1998) and concluded that this may be a good approach to estimate and understand the mechanisms regulating soil C stocks (Shaw et al. 2008). The advantage of using soil formation and pedogenic horizons in the $\mathrm{C}$ stock assessment is the gain of additional information on the nature of the soil organic matter and causal connections between environment and C dynamics. Internationally used soil classification systems reflect soil development, and organic matter is one of the key mediators in soil development (Van Cleve and Powers 1995). Processes involving organic matter lead to horizons with distinct chemical, physical and biological properties. The soil organic matter in both surface and subsoil are specific to different pedogenic processes, organic $C$ is therefore, one of the major differentiation criteria in all modern soil

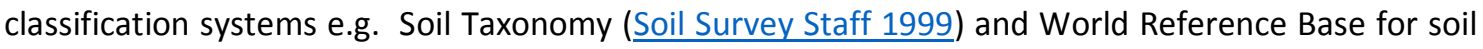


69 are considered more stable, and a change in land use e.g. from forest to cultivated land should not 70 influence the higher level classification. Soil classification should therefore not be expected to reflect 71 properties of the surface horizons of forest soils sufficiently to provide a good and reliable predictor 72 of $\mathrm{C}$ stocks in these soil layers. The Canadian soil classification system may, however, be an exception as also surface horizons may be diagnostic (Agriculture Canada Expert Committee on Soil Survey 1987). In the early 1980's the Canadian soil classification system was chosen as the most appropriate modern soil classification system to adapt to Norwegian conditions. Similarities in climate, parent material, and pedogenic age, in addition to having a nomenclature close to the old Scandinavian system (Frosterus 1923), favoured this choice.

No soil map of Norway exists detailed enough to provide any reliable estimate of soil carbon in Norway. Only crude estimates of total $\mathrm{C}$ stocks in Norwegian forest soils have been published previously e.g. (de Wit and Kvindesland 1999; Kjonaas et al. 2000). Though some publications have discussed C stocks in Norwegian forest soils in relation to parent material, climate e.g.(Callesen et al. 2003) and forest management (Nilsen and Strand 2008; Nilsen and Strand 2013) these are not representative for the Norwegian forest area in general. During the first forest inventory initiated by the International Co-operative Program on Assessment and Monitoring of Air Pollution Effects on Forests (ICP-forest) Norway compiled a forest soil database containing 1040 detailed soil profile descriptions down to $1 \mathrm{~m}$ or to bedrock with accompanying chemical and physical analysis. This database is unique as i) it includes all drainage classes ii) it covers the major Norwegian forest vegetation types and climate and iii) the soil pits were chosen in a systematic manner giving soil profiles that were representative for the forest plots. This offers a potential to explore $\mathrm{C}$ stocks in Norwegian forest soil according to pedology, as well as relationships to gradients in climate, vegetation, parent material and topography. Our main objective for this study is to provide an 
94 according to soil taxonomic units. Additionally, we examine sources of uncertainty and quantify the 95 uncertainty of the soil $\mathrm{C}$ stocks estimates at the scale of the soil profile and taxonomic unit. Further 96 we use the taxonomic stratification to explore the relationship particularly between the soil C stock, 97 climate, vegetation, drainage and soil depth. Finally we estimate total soil C stocks for the forest area of Norway.

\section{Materials and Methods}

\section{Forested area of Norway}

Norway spans over 13 degrees of latitude, and comprises an area of $324000 \mathrm{~km}^{2}$. Due to the Gulfstream and strong influence by westerly winds the climate is milder than expected compared to other countries on similar latitudes. Frequent and sharp changes in topography in addition to altitudes spanning from $0-1000$ meters above sea level over relatively short distances, contribute to considerable variation in the local climate. Excluding mountain areas, mean annual air temperatures (MAT) in Norway vary from -3.1 to $7.7^{\circ} \mathrm{C}$ (Aune 1993). Highest and lowest mean annual temperatures are found in the coastal southern and western Norway and in the inland eastern and northern Norway, respectively. Mean annual precipitation (MAP) ranges from 278 to $3575 \mathrm{~mm}$ (average for the period 1960-1990). Coastal western Norway receives the most and inland areas of eastern and northern Norway receive the least precipitation (Forland 1993). Most of the forested areas in Norway have parent material of till (morainic) or glacio-fluvial origin though areas of marine deposits, colluvium and peat are also found, all deposited after the last Ice age $(<12000$ years). The dominating till and glacio-fluvial parent material is generally transported over short distances and is of gneissic, granitic or quarzitic origin giving stony and coarse textured soils. 
117 Approximately $37 \%$ of Norway's land area is forested, $120344 \mathrm{~km}^{2}$ according to the Norwegian 118 Environmental Agency (2015). Of the total land area productive forest makes up $26.7 \%$ and the 119 remaining forested area is unproductive forest and mountain-birch forest (Granhus et al. 2012). 120 Approximately $70 \%$ of all forest is below 500 meters above sea level (m.a.s.I.). Most forest is found 121 in east and central Norway, Figure 1. Dominating tree species are Norway spruce (Picea abies (L.) 122 Karst.), Scots pine (Pinus sylvestris L.), and birch (mainly Downey birch (Betula pubescens (L.) Ehrh.) 123 and European white birch (Betula pendula Roth.)). Spruce dominates the productive forest area (> 1 $124 \mathrm{~m}^{3} \mathrm{ha}^{-1}$ year $^{-1}$, canopy cover $\left.>10 \%\right)$ while deciduous forest dominate in low productivity forest $(<1$ $125 \mathrm{~m}^{3}$ ha $^{-1}$ year $^{-1}$, canopy cover $<10 \%$ ). (Granhus et al. 2012). Approximately $6.6 \%$ of the productive 126 forest in Norway is characterised as old forest, that is forest that is considerably older than 127 recommended harvest age for the given forest stand (Granhus et al. 2012).

\section{The forest soil database}

For this study an existing land representative forest soil database, collected in connection with the

ICP forest monitoring program level 1 sites was used (Lorenz 1995). This database covers forest sites in a grid system $\left(9^{*} 9 \mathrm{~km}\right)$ from $5^{\circ}$ west to $30^{\circ}$ east, $58^{\circ}$ south to $70^{\circ}$ north and from 2 to 1190 meters above sea level (m.a.s.l.). The soil profile sampling points follow the forested area, thus there are few data from the northernmost county (Finnmark), central mountain areas and the coastal areas in general, see Figure 1.

A total of 1040 soil profiles were described, sampled and analysed between 1988 and 1992 (Esser and Nyborg 1992). Since that time, no other systematic area representative forest soil surveys have been conducted in Norway. Locations for soil profiles were chosen systematically, measuring $5 \mathrm{~m}$ northward from the centre of each forest monitoring plot then turning $90^{\circ}$ clockwise avoiding trees, 
141 stumps and boulders until a location representative for the plot was found. Soil profile descriptions 142 were done according to standardized procedures (Sveistrup 1984). Soil samples were taken from 143 each described horizon in the soil pit. Additional 5 - 10 samples were taken with an auger, spread 144 across the plot, and bulked together with the same horizons as described in the soil pit. Soil for chemical analysis was subsampled from a mixture of soil from the pit and from the bulked sample 146 (Esser and Nyborg 1992). In addition to information on soil properties and classification, the database contains general area data, information on topography and landform, forest (dominating tree species, stand age, forest maturity class ( 1 to 5 where 5 is mature), site index (stand height at age 40 years) and ground-vegetation (moisture classes 1=dry, 2= medium, 3=wet; nutrient classes 1=poor, 2=medium, 3=rich), parent material, drainage (drainage classes from excessively well drained=1 to very poorly drained $=13$ ) and groundwater relationships. Many of the field observations are registered as class-variables, and where appropriate, they have been converted to numerical values (mean class value). This applies for slope, aspect, stone and gravel content. Field determinations of texture classes for the fine earth fraction were done for all mineral soil horizons. Laboratory analysis of particle size distribution was only done for one horizon from each profile, two if there were lithological discontinuities. The soils were classified according to the Canadian soil classification system and standard chemical analyses were performed as required (Agriculture Canada Expert Committee on Soil Survey 1987). All sampled soil horizons were analysed for organic total $\mathrm{C}$ and $\mathrm{N}$ by dry combustion using a Perkin-Elmer $2400 \mathrm{CHN}$ element analyser. The total $\mathrm{C}$ analysis was interpreted as organic $\mathrm{C}$, as all Norwegian forest soils have acidic $\mathrm{pH}$ and therefore is not expected to contain inorganic C. The database contains no information on soil bulk density. Climatic data included mean annual precipitation (MAP) and mean annual temperature (MAT) and length of growing season given as the sum of days with a 24-hour average temperature of at least $5^{\circ} \mathrm{C}$. These were calculated for each forest inventory plot based on standard normals (1961-1990) and adjusted according to plot elevation, as provided by the Norwegian Meteorological Institute. 
The soil profiles were classified following the Canadian system of soil classification, in which the order level is based on similarities in soil profile development, and reflects major soil forming processes. The second level, the great group, reflects differences in development of the dominant soil forming process and the third level, the sub group, reflects intergrades towards other soil orders and special features not related to the dominating soil forming process (Agriculture Canada Expert Committee on Soil Survey 1987). Five soil orders, 15 great groups and 45 subgroups were present in the Norwegian forest soil database in addition to sites registered as non-soils (soils $<10 \mathrm{~cm}$ thick) (Table 1). In the present study, the soil taxonomic units were grouped according to processes believed to be important for accumulation and stabilization of organic matter in the soil. The following processes were identified as important 1) water saturation 2) podzolization 3) brunification 4) drought and root restriction due to restricted effective soil depth (Table 1).

\section{Calculation of $C$ stocks in soil profiles}

Definitions similar to those of Tarnocai (1998) were adopted: Total C stock in kilograms per square however a cut-off depth at $100 \mathrm{~cm}$ was used when calculating the profile carbon stock. Only $2 \%$ of

Horizon:

$$
\mathrm{C}_{\text {stock }}=\mathrm{BD} * \mathrm{C}_{\text {cont. }} * \mathrm{~T}^{*} \mathrm{CF}_{\text {coarse }}
$$

Profile:

$$
\mathrm{C}_{\text {stock }} \text { profile }=\left(\mathrm{C}_{\text {stock, horizon } 1}+\mathrm{C}_{\text {stock, horizon } 2}+\ldots+\mathrm{C}_{\text {stock, horizon } \mathrm{n}}\right)
$$


Where:

193 $/ 100$

For soils classified as mineral soils (Podzolic, Brunisolic, Regosolic and Gleysolic) the distribution of C stock between the LFH horizons and the mineral soil was expressed as the percentage of the total C stored in the mineral soil compartment for each profile.

Where data essential for calculating horizon $\mathrm{C}$ stocks were lacking we estimated the missing data using different approaches. For bulk density data this applied to all horizons. For mineral soil horizons we used a pedotransfer function developed by Honeysett and Ratkowsky (1989) and parameterized by Baritz et al. (2010) using a large European forest soil database.

$$
B D=1 /(0.564+0.0556 \times \text { SOM \%). (equation } 3 \text { ) }
$$

Where SOM is soil organic matter and set to be equal to $1.724 \times \% \mathrm{C}$

A separate database for published and unpublished data on organic and mineral soils from Norwegian forest soil (de Wit and Kvindesland 1999) contained measured bulk densities from forest soil horizons. Comparisons between measured and estimated bulk densities for this separate bulk density database showed that the Baritz et al. (2010) pedotransfer function was suitable for estimating the Norwegian bulk densities for mineral soil horizons $\left(r^{2}=0.65\right.$, slope $\left.=0.89\right)$ though slightly underestimating the measured bulk densities. No satisfactory pedotransfer function could be 
215 made for the organic horizons, instead the median bulk density values from the separate soil data 216 base (785 organic horizons) were used to estimate the bulk densities of the organic horizons with 217 equivalent horizon designations.

218 Information on stone content was missing from $6 \%$ of the mineral soil horizons and $15 \%$ had no 219 information on gravel content. As the stone and gravel content in the database were registered as 220 class variables, these were converted to the mean of the lower and upper class limit. Both gravel and 221 stone classes were given as volume percent per horizon: four gravel classes $(<20,20-50,50-90$ and $222>90)$, and seven stone classes $(<0.1,0.1-2,2-5,5-10,10-20,20-40$ and $>40)$. Where nothing else was stated, we assumed that there were no stone or gravel in organic horizons. If one or more of the mineral soil horizons within a profile lacked gravel and stone information and no shift in lithology was indicated, we used the average of the above and below horizons. If only one horizon contained information on gravel and stone content this was used for all mineral soil horizons. If all information on coarse material was missing from the profile, the median of all coarse fraction data in mineral soil horizons of the same parent material was used.

Ten percent of all horizons had no information on C concentration. These were mostly thin horizons or transitional horizons. We estimated the missing values by applying the mean of the horizons immediately overlying and underlying the horizon. Fifteen percent of the profiles had no exact information on the thickness of the deepest horizon, in this case the lowest horizon was assumed to have a thickness of $20 \mathrm{~cm}$.

The pedological approach to soil $\mathrm{C}$ stock assessment means that systematic variation in the $\mathrm{C}$ stock 238 data are assigned to master horizon type and a layer volume defined by horizon thickness measured 
239 in the profile. Uncertainty, i.e. random error in the soil organic C estimates in each profile arises 240 from stone and gravel content, which is given in class intervals of non-uniform size, from soil 241 sampling and the following $\mathrm{C}$ concentration determination in the fine earth fraction, and from the 242 bulk density assumptions made. The $C$ stock of a given profile is, depending on the number of 243 horizons described, the sum of 4-7 summed products (equation 2). Each soil layer is a product of the 244 four factors; layer volume, stone and gravel content, bulk density and C concentration (equation 1).

The uncertainty arising from the stone and gravel assessment as a class variable with increasing interval sizes, and the bulk density assumptions based on the pedotransfer function (equation 3) was simulated for each horizon. A relative error of $2 \%$ was used for measured C concentrations between 1 and $10 \%$ while the relative error was doubled (+/- $4 \%)$ for concentrations lower than $1 \%$ and for concentrations larger than $10 \% \mathrm{C}$. The reason for differentiating the relative error for the $\mathrm{C}$ concentration is that random errors for e.g. sampling will be larger both at low concentrations (in laboratory) and for high concentrations (during field sampling). For the bulk density relative errors of $+/-5,10$ and $20 \%$ of the simulated bulk density was assumed. For the coarse fraction two approaches were tested using either 1) uniform distribution within the field registration class limits for gravel and stone content, so that each value in the interval had the same probability, or 2) the mid-class stone content from the field registration class, e.g. the stone content would be $15 \%$ in the $10-20 \%$ class.

Ten typical soil profiles from the forest soil database were chosen for the simulation of $\mathrm{C}$ stock estimate uncertainty (Table 2). These profiles had C stocks close to the median of the soil group they represented. The horizon data from each of these profiles formed the background data for the Monte Carlo (MC) simulation. The MC simulations were run 1000 times per profile (with calculations 
263 by horizon) and the sum of the $\mathrm{C}$ stock for the representative profiles was calculated. The mean and 264 standard error of the resulting C stock simulations for each profile were calculated.

Estimates of forest soil C stocks ( $\mathrm{C}$ in soil) were calculated by multiplying the Ismean C stocks with corresponding area estimates for each soil type and expressing this as gigaton carbon (Gt C). The uncertainty estimates were done by two different methods; i) one for each of the soil groups where we expect the uncertainty regarding the areas will be larger for the less frequently occurring soils; ii) a second method for the National forest soil total C stock using the same area uncertainty as that applied by the national forest inventory (Norwegian Environment Agency 2015).

Areas for each of the soil groups were found based on the assumption that the distribution of soil types in the database represent equivalent proportions of soil cover in the forested area in Norway. The standard error (SE) for each soil group area was found by first calculating the standard error connected to the proportion $(p)$ of each soil group SE $=\sqrt{p(1-p) /(n-1)}$ where $\mathrm{n}=$ number of total observations. This standard error connected to the proportion was thereafter used to calculate the coefficient of variances (CVarea) for the corresponding area. The coefficient of variances of the soil group mean SOC estimate (CVSOC) was calculated from the SE of the simulated profiles and the group Ismean (see Table 5, Table 3). Assuming that errors between factors are uncorrelated we then calculated CVtotal $=\sqrt{(\text { CVarea })^{2}+(\text { CVSOC })^{2}}$ for $\mathrm{C}$ stocks of each soil group ( $\underline{\text { Snedecor and }}$ Cochran 1967). on the Ismean for each of the soil types as described above. The uncertainty estimates for the total 
287 forested area of Norway (CV for total forested area) was set to $2 \%$ as based on registrations by the 288 National forest inventory (Norwegian Environment Agency 2015). The variance of the total SOC 289 stock was found summing the weighted group variances and from this a CV of $2.8 \%$ was calculated. 290 The total uncertainty, was then $\mathrm{CV}=\sqrt{(2)^{2}+(2.8)^{2}}$ equalling 3.4\%. Finally the mean total forest soil 291 C stock and confidence intervals (CL95\%) were regulated downward with by $8 \%$ as a consequence of 292 the skewed mean.

\section{$\underline{\text { Statistical analyses }}$}

Differences in soil $\mathrm{C}$ stocks between the different soil groups were analysed by one-way ANOVA. Multiple comparisons of means between the different classes were done using the StudentsNewman-Keuls multiple range-tests on all main effects (SAS Institute 1990). Estimates of $95 \%$ confidence limits on least significant means were made using the LSMEANS procedure. All correlation analyses were done by the non-parametric Spearman method in the CORR procedure of the SAS software package (SAS Institute 1990). The Monte Carlo simulation was run using the $\mathrm{R}$ package "foreach" (R 3.1.2) (R Development Core Team 2010).

\section{Results}

\section{Total C and N Stocks and C:N-ratio}

The largest amounts of $\mathrm{C}$ were found in the soils dominated by water saturation processes. These comprise $32 \%$ of the soils in the database (Table 3). Among these, the largest $C$ stocks were in the Organic-wet soils, and declining from Gleysolic, gleyed Podzolic to gleyed Brunisolic. Among the selfdrained soils not restricted by bedrock, the total soil C stocks ranged from $11.2 \mathrm{~kg} \mathrm{C} \mathrm{m}^{-2}$ in Regosolic soils to $15.9 \mathrm{~kg} \mathrm{C} \mathrm{m}^{-2}$ in the self-drained Brunisolic soils, Table 3. The Organic-folisols and the non- 
312 soils are both restricted in depth by bedrock (Table 1). Nevertheless, the Organic-folisols stored 10.3

$313 \mathrm{~kg} \mathrm{C} \mathrm{m}^{-2}$ on average. The Podzolic soils had a larger fraction of profile $\mathrm{C}$ in mineral soil (about $60 \%$ )

314 compared with other mineral soils. The soils with the lowest proportion of $\mathrm{C}$ stock in the mineral

315 soils were the Regosolic ( $36 \%$ ) and the Gleysolic (41 \%). Although the self-drained Podzolic and

316 Brunisolic store approximately equal amounts of $C$ in total, there was a significant difference in the

317 proportion stored in the mineral soils with $60 \%$ versus $47 \%$ for the Podzolic and the Brunisolic soils

318 respectively (Table 3).

The $\mathrm{N}$ stocks of the mineral soils were in the range of 0.1 to $1.1 \mathrm{~kg} \mathrm{~N} \mathrm{~m}^{-2}$ with water saturated soils showing a tendency for higher $\mathrm{N}$ stocks than self-drained soils (Table 4). Additionally, less $\mathrm{N}$ was stored in the poorly developed Regosolic soils and Non-soils. The C:N ratios of eluviated and gleyed Brunisolic soils were higher than other mineral soils (Table 4) due to low $\mathrm{N}$ concentrations.

The distribution of soil $\mathrm{C}$ stock was estimated by soil order and master horizon with typical subhorizon suffixes in Figure 2. The confidence limits were narrowest for the uppermost horizons and widen downward for all soils types. Particularly the self-drained Brunisolic soils exhibit a large variability in C stocks in the deeper horizons. The largest soil group within the soil database is the self-drained Podzolic. This is also reflected in the narrow confidence limits connected to the $C$ stock estimates of all horizons. Soils with podzolization as the dominating process, here represented by the gleyed Podzolic, self-drained Podzolic and the eluviated dystric Brunisolic soils, showed no significant differences in $\mathrm{C}$ stock $\left(6-8 \mathrm{~kg} \mathrm{C} \mathrm{m}^{-2}\right)$ or in thickness of the LFH horizon, Figure 2. The same soil groups were significantly different with respect to $\mathrm{C}$ stocks in the Ae horizon (gleyed Podzolic>self-drained Podzolic>eluviated dystric Brunisolic), though there were no significant differences in Ae horizon thickness. The eluviated dystric Brunisols soils were significantly lower in C stocks also in the B horizons, which is also due to a significantly thinner B horizon. 
The self-drained Podzolic and Brunisolic soils differed in C-stock distribution within the profile, even though approximately storing equal amounts of $C$ in total (Table 3). The self-drained Brunisolic stored significantly more in the upper horizons both in the LFH and the A horizon (Figure 2) whereas the Podzolic stored significantly more in the B horizon.

Among the soils influenced by water saturation, but excluding the Organic-wet soils, the Gleysolic had significantly larger $\mathrm{C}$ stocks and thicker LFH horizons compared with the gleyed Podzolic and gleyed Brunisolic soils. The C stocks of the LFH horizons of the Gleysolic were the largest of any of the forest floors of the mineral soil; more than $13 \mathrm{~kg} \mathrm{C} \mathrm{m}^{-2}$ in average. There are significantly higher $\mathrm{C}$ stocks in the B horizon of the gleyed Podzolic than those of the Gleysolic or Brunisolic B horizons.

The results from the Monte Carlo simulation for each of the typical profiles sampled from the dataset are given in Table 5. In most cases the simulated C stocks were close to the $\mathrm{C}$ stock based on all profiles (Table 3) and the two different coarse-fraction representations used in the simulations gave similar results. The absolute standard error of 1000 simulated SOC stock values within each soil order profile example ranged from $0.1-1.9 \mathrm{~kg} \mathrm{C} \mathrm{m}^{-2}$ with $5 \%$ relative $\mathrm{BD}$ error and increasing to a range of $0.3-6.2 \mathrm{~kg} \mathrm{C} \mathrm{m}^{-2}$ for $20 \%$ relative $\mathrm{BD}$ error. The simulations using mid-class of coarse fraction produced C stocks that were 0.8 to $0.9 \mathrm{~kg} \mathrm{C} \mathrm{m}^{-2}$ higher than uniformly distributed stone content for Gleysolic and Brunisolic soils, whereas other estimates showed only little bias, i.e. only slightly higher stock estimates with the mid-class approach. 
361 The relationship between soil C stocks of the most frequent soil order, the Podzolic, and the climate

362 parameters, MAP and MAT is illustrated in Figure 3. The Figure shows that both low and high soil C

363 stocks within the soil order can be found in the cold and dry as well as the relatively warm and wet

364 areas of Norway. Despite the large variation, significant positive correlations were found for $\mathrm{C}$ and $\mathrm{N}$

365 stocks of Podzolic soils, with both MAT and MAP (Table 6). However, only MAP showed a significant

366 positive correlation with the $\mathrm{C}$ and $\mathrm{N}$ stock of the Brunisolic-eluviated soils. Among the self-drained

367 Podzolic soils there was a significant and positive correlation between the percentage of $C$ stocks in

368 the mineral soil and MAP. Among the Organic - wet soils, the peats, total $\mathrm{C}$ and $\mathrm{N}$ stocks were

369 negatively correlated to MAT, Table 6. This coincides with a significantly negative correlation

370 between MAT and peat depth $(r=-0.40, p<0.0001)$. For the Organic - folisols, the thin organic soils

371 restricted by bedrock, both $\mathrm{C}$ and $\mathrm{N}$ stocks were significantly and positively correlated with both

372 MAT and MAP. For the other soil groups there were little or no correlation in $\mathrm{C}$ and $\mathrm{N}$ stocks to any

373 of the climatic variables, Table 6.

\section{C and $N$ stocks related to vegetation}

Soils under pine forest show a wide range in soil C stocks and represent the most frequent forest type for both the soils with low $\mathrm{C}$ stock and those with high, Figure 4 . When excluding the Organic and Non-soils, significant differences in both $\mathrm{C}$ and $\mathrm{N}$ stocks were found among forests dominated by spruce, pine and deciduous trees. For total $\mathrm{C}$ stocks the order was spruce>pine>deciduous while for $\mathrm{N}$ stocks pine and deciduous forest switched places. There were also a significant difference in forest floor C:N ratio between the three dominating tree species where pine>spruce>deciduous. Soils under pine forest also had significantly lower $\mathrm{C}$ stocks in the mineral soil compartment compared to soils under spruce and deciduous forest. Among the self-drained and gleyed Podzolic soils there was 
386 C stored in the mineral soil (Table 7). In the group of self-drained Podzolic soils, increasing forest 387 stand maturity was positively correlated with total C stock, C stock in forest floor and with C:N ratio. 388 For the self-drained Podzolic soils there was a significant negative correlation between the site index 389 and the $\mathrm{C}$ stocks in the forest floor and a significant positive correlation between site index and total $390 \mathrm{~N}$ stocks and the percentage of $\mathrm{C}$ stored in the mineral soil (Table 7). Ground vegetation was registered according to a moisture gradient (dry, medium, wet) and to a nutrient gradient (poor, medium, rich). The moisture gradient was significantly and positively correlated with the total C stocks within a wide range of soils: Organic - wet, Gleysolic, self-drained Podzolic, eluviated and gleyed Brunisolic, and Regosolic soils. The ground vegetation nutrient gradient, however, had a significantly negative correlation to the total C stock of the Gleysolic. The influence of the nutrient gradient on C stock in the mineral soil compartment was more evident, where ground vegetation nutrient level was significantly and positively correlated with the proportion of $C$ stored in the mineral soil compartment of Gleysolic, Podzolic, as well as self-drained Brunisolic soils while there was a significantly and negatively correlated with the C stored in the forest floor (Table 7). The nutrient level was also reflected in the $\mathrm{C}: \mathrm{N}$ ration of the forest floor showing significantly negative correlations for all soil groups except the Organic and Non-soils.

402

For all soils, except the Gleysolic and the eluviated and gleyed Brunisolic soils, total C stocks showed significant positive correlations with soil depth. The factor restricting the non-soil and the Organic folisols is bedrock, while rocks and coarse fraction in addition to bedrock may restrict the soil depth in the other soil groups (Table 8). Ranking soil drainage from excessively well drained (1) to very poorly drained (13) showed that there was a large variation in drainage class also among the shallow Organic - folisols soils giving a significant positive correlation between total $\mathrm{C}$ stock and drainage 
411 stock and drainage was also found, except for the self-drained Brunisolic soils. Depth to

412 groundwater was only registered when this occurred within the depth of the soil profile described.

413 For the self-drained and gleyed Podzolic and the self-drained Brunisolic soils, there was a significant

414 positive correlation between registered depth to groundwater and total C stock (Table 8).

417 The total $\mathrm{C}$ stock assuming $120000 \mathrm{~km}^{2}$ forest area, was estimated to $1.83 \mathrm{Gt} \mathrm{C}$ with confidence

418 limits between 1.71 and $1.95 \mathrm{Gt}$ C. This was achieved after summing the group Ismeans (Table 9) 419 deducting $8 \%$ due to skewed mean and assuming a $2 \%$ uncertainty for the total forest area. The 420 estimates for each soil group indicate that $36 \%$ of the forest soil $C$ stock are found in the self-drained 421 Podzols. Poorly drained soils with large proportions of C stored in the organic horizons store $40 \%$ of 422 the total forest soil C: $20 \%$ in the Organic-wet, $10 \%$ in Gleysols and $10 \%$ in the gleyed Podzolic soils 423 (Table 9). More than $50 \%$ of all soil C in Norwegian forest appear to be stored in soils with podsolization as the dominating soil forming process, including the eluviated Brunisolic soil, selfdrained and gleyed Podzolic. The uncertainties in the C stocks for each soil group are connected to the forest area and C stocks estimates and range from $0.9 \%$ to $2.4 \%$ and are largest for carbon rich soil groups with few observations in the soil database (Table 9).

\section{Discussion}

430 Soil carbon and nitrogen stocks according to soil type

431 The largest $\mathrm{C}$ and $\mathrm{N}$ stocks, at the profile level, in the Norwegian forest soil database were found in 432 the Organic-wet soils. These are the Humisols, Mesisols and Fibrisols of the Canadian Organic soil 433 order formed due to excess water and anaerobic conditions. Among the Organic -wet soils $47 \%$ 434 belong to the Terric sub-groups, indicating shallow peats with mineral soil layers or bedrock 435 appearing between $60-160 \mathrm{~cm}$ depth. The large proportion of these shallow peats is probably the 
436 reason why Organic-wet store less C than reported for other Organic or Histosol soils in boreal 437 forests (De Vos et al. 2015; Tarnocai 1998). The bulk densities used for calculating the C stocks in the 438 organic horizon of the Organic-wet soils are in the range expected in Nordic forested peats (Laiho et 439 al. 2004) but lower than those given for European forest peats in De Vos et al. (De Vos et al. 2015).

Considering the mineral soils, the Canadian soil classification system on order level provides significant differences with regard to $\mathrm{C}$ and $\mathrm{N}$ stock in the order Gleysolic $>$ Podzolic $>$ Brunisolic $>$ Regosolic soils. Our ranking is consistent with those reported for Canadian forest soils with the exception of the Regosolic soils which in our study have the lowest C stocks $\left(10.8 \mathrm{~kg} \mathrm{C} \mathrm{m}^{-2}\right)$, while Shaw et al. (2008) report high stocks $\left(18.5 \mathrm{~kg} \mathrm{C} \mathrm{m}^{-2}\right)$, i.e. in the same range as the Gleysolic soils. Our explanation for this difference is that a large proportion of the Norwegian Regosolic soils are shallow bedrock-restricted soils, $66 \%$ of the Regosolic soils are $\leq 35 \mathrm{~cm}$ deep. The average $\mathrm{C}$ stocks for Norwegian soil orders are generally higher than those reported in the Canadian study (Shaw et al. 2008). The main difference between the two studies is that the Norwegian soils have larger stocks in the organic horizons (LFH- horizons). Studies of Danish forest soils (Callesen et al. 2015; Vejre et al. 2003) showed that the C stocks of comparable soil units were similar to those found in our study, however, also here our study show larger $\mathrm{C}$ and $\mathrm{N}$ stocks in the forest floor and lower $\mathrm{C}$ stocks in the mineral subsoil. A recent study of boreal and temperate forest soils in 22 european countries (Norway not included) (De Vos et al. 2015) reported similar C stocks and ranking between comparable soil orders, except for Podzols which have much lower C stocks than found in our study. Podzolization is the dominant soil forming process in Norwegian forest soils; $55 \%$ of the soils in the forest soil database show a podzol morphology reflected in the classification. In addition to the soils in the Podzolic order also the Eluviated Dystric Brunisols of the Brunisolic order have a clear podzol morphology but do not meet the depth or chemical classification criteria for the Podzolic order. The 
461 Finland, 5-8 $\mathrm{kg} \mathrm{C} \mathrm{m}^{-2}$ down to 1 meter and Sweden $6.5-9.5 \mathrm{~kg} \mathrm{C} \mathrm{m}^{-2}$ down to $0.5 \mathrm{~m}$ (Liski and

462 Westman 1997; Olsson et al. 2009). Our findings were more in line with Danish and Canadian

463 studies. Vejre et al. (2003) and Callesen et al. (2015) reported C stocks for Danish forest Podzols

464 down to $100 \mathrm{~cm}$ and including forest floor of 14.6 and $16.9 \mathrm{~kg} \mathrm{C} \mathrm{m}^{-2}$ respectively. Shaw et al.

465 (2008)and Tarnocai (1998) reported C stocks of 15.6 and $19.3 \mathrm{~kg} \mathrm{C} \mathrm{m}^{-2}$ respectively for Canadian

466 boreal forests Podzolic soils. Some of the discrepansies between the estimates of Podzol C stocks

467 particullarly for the Nordic coundries may be due to differences between classification system and

468 identification criteria for Podzols (Agriculture Canada Expert Committee on Soil Survey 1987; FAO

469 Unesco 1990; Soil Survey Staff 1999; WRB 2015). The weakly developed soils with podzol

470 morphology, the Eluviated Dystric Brunisols in our study have a total $\mathrm{C}$ stock of $11.2 \mathrm{~kg} \mathrm{C} \mathrm{m}^{-2}$ down

471 to $50 \mathrm{~cm}$ and a $\mathrm{C}$ stock in the mineral soil down to $50 \mathrm{~cm}$ of $4.2 \mathrm{~kg} \mathrm{C} \mathrm{m}^{-2}$ which is more in accordance

472 with the Swedish Podzols (Olsson et al. 2009).

The Organic-folisols and non-soil (soil depth $<10 \mathrm{~cm}$ ) are the soil groups with lowest $\mathrm{C}$ stocks. There

475 are few studies that report $\mathrm{C}$ stock from such soils in forested areas. However, particularly the

476 Organic-folisols store considerable amounts of $C$ and represent a soil type frequently occuring in

477 Norway in the transition between forest and heath and moorland areas. The C stocks of the

478 Organic-folisols are within the range suggested for organic rich Leptosols in moorlands of Scotland

479 (Stutter et al. 2009) and Northern England (Tipping et al. 2007) as well as for Norwegian heathland areas (Strand et al. 2008).

481

The main reason for the higher $\mathrm{C}$ stocks in organic horizons of Norwegian forest soils appears to be greater horizon thickness and higher bulk densities. Compared with organic horizon thicknesses reported from other Nordic contries (Liski and Westman 1995; Vejre et al. 2003), Norwegian organic surface horizons are thicker. However, O horizons of Podzols investigated by Olsson et al.(2009) had 
an average thickness of $8.2 \mathrm{~cm}$, thus similar to the average for the organic horizons of the Podzolic 487 soils in this study which was $9.6 \mathrm{~cm}$. The bulk density data we used for calculating the $\mathrm{C}$ stocks of 488 the organic horizons were collected from various sources and although all were from Norwegian 489 forest soils they are not necessarily representative for those of the forest soil database. Standard core sampling were used to determine these bulk densities and compression of the organic soil may have introduced artificially high bulk densities. However, the median bulk density values used for our calculations were $110-171 \mathrm{~kg} \mathrm{~m}^{-3}$, which is well within the range reported for similar horizons e.g. (De Vos et al. 2015). For norwegian forests, the average bulk density was $165 \mathrm{~kg} \mathrm{~m}^{-3}$ for the organic horizon above mineral soils were similar to the bulk densities of the more decomposed $\mathrm{OH}$ horizons and hydromorphic or semi-terrestrial organic horizon reported by De Vos et al. (2015). The C concentration in the organic horizons, mean $39.5 \%$ with $95 \%$ confidence limits between 38.8 and 40.3 is similar to the range reported in other studies eg (De Vos et al. 2015; Olsson et al. 2009; Vejre et al. 2003).

Our error estimates using the standard error on profile soil C stock estimates based on uncertainties in bulk density, coarse fraction and $C$ content for a representative set of soil profiles (Table 5) indicate that the largest errors are found in the Organic (1.9-6.2 $\left.\mathrm{kg} \mathrm{C} \mathrm{m}^{-2}\right)$, Gleysolic (1.1-3.7 $\mathrm{kg} \mathrm{C} \mathrm{m}^{-}$ ${ }^{2}$ ) and gleyed soils $\left(1.0-3.7 \mathrm{~kg} \mathrm{C} \mathrm{m}^{-2}\right)$, less for the self-drained mineral soils $\left(0.7-3.2 \mathrm{~kg} \mathrm{C} \mathrm{m}^{-2}\right)$. These errors are not large enough to explain the differences between $C$ stocks in our study and those of other comparable studies.

\section{Cand $N$ stocks related to climate}

Relationships between soil C stock and MAT and MAP were not obvious, evidently other more site 509 specific parameters have a larger influence on the soil C stocks. Even though they were calculated 
510 for each forest inventory plot, correcting for altitude, MAT and MAP are still macro-climatic

511 parameters that do not necessarily reflect the local climate or seasonal variations important for soil

512 C accumulation. Norway has a highly variable topography which modifies the local climate.

513 Interaction between temperature and topography was also pointed out by Johnson et al. (2011) as

514 being of major importance for controlling soil $\mathrm{C}$ stock in high-latitude systems. However, for the

515 Podzolic soils there were a significant positive correlations between both $\mathrm{C}$ and $\mathrm{N}$ stock and MAT and

516 MAP (Figure 3, Table 6). For the self-drained Podzolic soil, MAP was also positively correlated with

517 the proportion of $C$ in the mineral soil compartment. However, this was not the case for the wetter

518 gleyed Podzolic where the increase in soil C stock was mostly connected to the organic horizon. This

519 is in accordance with Olsson et al. (2009) study of Swedish Podzols. Callesen et al. (2003) and De Vos

520 et al. (2015) also found that both MAT and MAP were important for total forest soil C stock, but that

521 MAP was of relative greater importance than MAT for mineral soil $C$ stocks. Warm and humid

522 environments enhances forest productivity increasing both litter production and decomposition

523 (Van Cleve and Powers 1995), while a precipitation surplus will transport organic compounds

524 downwards in the soil profile were it may be illuviated and stabilized in the mineral soil, processes

525 characteristic of podzolization e.g. (Lundstrom et al. 2000). Periodic water saturation and fluctuating

526 ground water table as found in the gleyic Podzolic may obscure these transport, sorption and

527 stabilization processes. The negative correlations between C:N ratios of the forest floor and MAP

528 and MAT for the self-drained Podzolic, Table 6, correspond to the findings of Callesen et al. (2007)

529 for forest floor of Nordic well drained forest soils. This negative correlation with MAT and MAP could

530 either be ascribed to the initial litter quality determined by forest and ground vegetation, or to

531 increased humification, or the ecosystem $\mathrm{N}$ status being more favourable in areas with higher MAT

532 and MAP. Olsson et al. (Olsson et al. 2009) found that of all site factors investigated $\mathrm{N}$ deposition

533 showed the strongest positive correlation with soil C stocks for Swedish Podzols. In Norway areas

534 that receive the higher $\mathrm{N}$ deposition coincide with the areas that receive the highest precipitation 
$535(\underline{\mathrm{Sft} 2006)}$ and MAP and MAT are positively correlated $(r=0.69, p<0.0001)$ making it difficult to 536 separate these effects.

538 For the Organic - wet soils there was a significantly negative correlation between the $\mathrm{C}$ and $\mathrm{N}$ stock 539 and MAT and length of growing season but no correlation with MAP (Table 6). The fact that there 540 was a significant negative correlation between the profile depths of the Organic-wet soils and MAT $541(r=-0.39, p<0.0001)$ could explain the negative correlation between $\mathrm{C}$ and $\mathrm{N}$ stocks and MAT. Most of 542 the forested Organic soils were drained at some point as a forest management practice to promote 543 forest productivity. Lowering of the ground water table gives better aeration accelerating the 544 decomposition more in warmer parts of the country than in colder. As many of the Organic-wet soils 545 are in the Terric subgroup, a loss of $\mathrm{C}$ due to decomposition would be more evident than in deeper 546 peat soil. The lack of correlation with MAP shows that the peat formation in these forested areas 547 probably is more due to topographically impeded drainage than to precipitation surplus. Contrary to 548 the Organic-wet soils the $\mathrm{C}$ and $\mathrm{N}$ stocks of the Organic-folisols were positively correlated to both 549 MAT and MAP, Table 6, suggesting that the $\mathrm{C}$ and $\mathrm{N}$ stocks are more related to vegetation and 550 productivity.

553 There were no differences between soil C stocks under Pine and Spruce dominated forests, however 554 significantly less $\mathrm{C}$ was found in soils under deciduous forest (Figure 4). This could be ascribed to 555 spruce being the dominating tree species in productive forests while deciduous forest dominates in 556 less productive forest (Granhus et al. 2012). Alternatively the lower soil C stocks in forest dominated 557 by deciduous tree species could be explained by a more rapid $C$ turnover as suggested by Melvin et 558 al. (2015) after comparing soil C stock in Black spruce and Paper birch dominated boreal forest in 
559 Alaska. Spruce-dominated forest have a larger proportion of the C stock in the mineral soil, 560 suggesting that more soil $\mathrm{C}$ is stabilized by minerals. Pine differed from spruce dominated forest by 561 being represented more frequently on soils with both low and high C stock (Figure 4). Pine appears 562 to adapt more to adverse growing conditions ranging from the poorly drained Organic - wet to the 563 excessively well drained Organic - Folisols and Non-soils. Pine-dominated forest also has a larger 564 proportion of the $\mathrm{C}$ stock in the forest floor suggesting that disturbances, such as site preparation 565 and drainage, probably would cause significant C loss. De Vos et al. (2015) found that humus forms 566 and tree species were the most useful predictors for $\mathrm{C}$ stocks in the forest floor. Our results confirm 567 this for the dominating tree species in Norwegian forests. For the $\mathrm{N}$ stock the differences was not 568 reflected in the forest floor but in the mineral soil compartment.

Forest stand age and forest stand maturity class reflect the rotation length between harvests. Several studies have suggested that an increase in rotation length would increase the $\mathrm{C}$ stocks in the 572 forest system e.g. (de Wit and Kvindesland 1999; Jandl et al. 2007). Only the self-drained Podzolic 573 soils showed any significant positive correlation between forest stand age, forest maturity class, and 574 total soil C stocks as such. However both the self-drained and the gleyed Podzolic soils showed a significantly positive correlation between forest stand age and the $\mathrm{C}$ stocks of the forest floor and a significantly negative correlation between forest stand age and the proportion of $\mathrm{C}$ stored in the mineral soil (Table 7). This suggest that increasing the rotation length only increase the more labile $\mathrm{C}$ stock in the forest floor and does not contribute to any increase of more stable $C$ stock in the mineral soil horizons. For Swedish Podzols Olsson et al. (2009) found no significant correlation between site index (equivalent to site capacity in their paper) and total soil C stocks, but contrary to our study they found a positive correlation between site index and the $\mathrm{C}$ stocks of the $\mathrm{O}$ horizon. As stated by Olsson et al. (2009) the relationship between site index and C stocks is complex. The more fertile sites may have a more rapid turnover suggesting lower $\mathrm{C}$ stock, a greater translocation of $\mathrm{C}$ to 
584 deeper soil horizon, more fine roots in deeper mineral soil horizons which fits with our observations. 585 However higher productivity also gives larger inputs of litter. The denser forest stands are often 586 found in high site index, which, through blocking sunlight and intercepting rainfall in the dense 587 canopy may induce colder and dryer soil conditions adverse to decomposition, thereby promoting 588 higher C stocks in the forest floor. However, no support for this was found in our study.

We found that ground vegetation classified according to moisture were good indicators of $\mathrm{C}$ and $\mathrm{N}$ stocks particularly for the forest floor. While the ground vegetation nutrient classes were better indicators of the proportion of $C$ in the mineral soil horizon. Combining ground vegetation moisture and nutrient classes should give a good indication of the total soil C stock. Particularly for the moist vegetation may play a key role in C dynamics particularly in Boreal ecosystems (Turetsky et al. 2012).

We found that soil C stocks increase with more poorly drained soils, this goes for all soil types but for the soil groups where drainage is part of the classification criteria this relationship was not always evident (Table 8). The soils classified as Gleysolic or as gleyic great groups or sub groups of other orders store nearly $4 \mathrm{~kg} \mathrm{C} \mathrm{m}^{-2}$ more $\mathrm{C}$ than the self-drained soils (Table 3, Figure 2). Virtually all of this was due to larger stocks in the organic surface horizon. Other studies have also shown that poor drainage results in higher C stocks particularly in the organic horizon e.g. (Tan et al. 2004). Organic matter in these horizons has little or no interaction with mineral soil material, the main stabilizing 
608 factor being water-saturation. Draining these poorly drained soils will probably cause an increase in

609 loss of $\mathrm{C}$ due to accelerated decomposition which may or may not be compensated by increased

610 productivity (Jandl et al. 2007). We also found a clear correlation between C stocks and drainage

611 classes in the self-drained soils. Olsson et al. (2009) also found an increase in C stock from dry to

612 fresh to moist sites for Swedish forest Podzols and that this increase was exclusively related to

613 differences in the $\mathrm{C}$ stocks of the O-horizon. They suggest several possible explanations for this

614 ranging from reduced decomposition due to periodic water saturation, high production of litter,

615 differences in litter quality and differences in distribution of root litter. Kleja et al. (2008) found more

616 fine root litter in the $\mathrm{O}$ horizons and less fine roots in the mineral soils of moist Podzols compared to 617 dry Podzols.

The Norwegian Organic-folisols are shallow soils lying directly on bedrock. These soils are extremely exposed to changing seasonal weather conditions. The bedrock micro-topography providing pockets for accumulation of particles and water as well as erosion areas experiencing extreme drought. The rapidly changing moisture conditions influence decomposition processes, plant growth and litter

623 production and thereby accumulation of soil C, however, forest management practices will have 624 minor effect on the $C$ stocks in these soils.

627 The estimates for the mean total $C$ stocks in Norwegian forest soil $1.83(1.71-1.95) G$ t $C$ is larger 628 than the $1.6 \mathrm{Gt} \mathrm{C}$ previously published in Kjonaas et al. (2000) for a comparable forest area. Kjonaas 629 and co-workers used data from the same database as us but only differentiated between organic 630 and mineral soils. In the present study we calculated the total forest soil $\mathrm{C}$ stock by summing the 631 total $\mathrm{C}$ stock of different soil groups assuming that their presence in the soil database is 
632 representative for area covered by soil groups in Norwegian forest. This may introduce additional 633 uncertainties but will hopefully provide useful information to government agencies seeking best 634 management practice for forestry with regard to forest soil C sequestration. A substantial part (40 \%) 635 of the Norwegian forest soil C is found in poorly drained soils that may all be particularly sensitive to 636 environmental change and management.

637

638

639 


\section{Conclusion}

642 Carbon and $\mathrm{N}$ stocks in Norwegian forest soils of different taxonomic classes vary from $10.8 \mathrm{~kg} \mathrm{C} \mathrm{m}^{-2}$ 643 and $0.43 \mathrm{~kg} \mathrm{~N} \mathrm{~m}^{-2}$ for the Regosolic soils to $31.3 \mathrm{~kg} \mathrm{C} \mathrm{m}^{-2}$ and $1.10 \mathrm{~kg} \mathrm{~N} \mathrm{~m}^{-2}$ for the Organic-wet soils. 644 Shallow soils $(<30 \mathrm{~cm})$ restricted by bedrock may store between 2 and $10 \mathrm{~kg} \mathrm{C} \mathrm{m}^{-2}$. Assuming a 645 forest area in Norway of $120000 \mathrm{~km}^{-2}$ and that the forest soil database is representative for the 646 Norwegian forest, the total forest soil C stocks for Norway was estimated to 1.83 Gt C with CL95\% $6471.71-1.95 \mathrm{Gt} \mathrm{C}$. The self-drained Podzolic and Brunisolic soils cover approximately $52 \%$ of the 648 forested area and we estimate that they may store $48 \%$ of the total forest soil C stocks. For the 649 Podzolic soils there were a positive relationship between total C stocks, temperature and 650 precipitation. Mean annual precipitation was particularly important for the $\mathrm{C}$ stored in the mineral 651 soil. Poorly drained soil types cover approximately $32 \%$ of the forest area and we estimate that they 652 may store approximately $47 \%$ of the total forest soil C. The C stocks in the forest floor were 653 generally high compared with estimates from other studies of boreal forests, and largest in soils with 654 periodic or permanent water-saturation. There was no significant difference between total soil C 655 stocks under spruce and pine forest but these store more than soils under deciduous forest, 656 probably reflecting that deciduous tree species were more common in low productive forest. Soils 657 under pine forest had larger $\mathrm{C}$ stocks in the forest floor and was more frequently occurring on wet 658 and peaty soils. For spruce forest more of the soil $C$ stock was found in the mineral soil 659 compartment. This suggests that the $C$ stocks under pine forest may be most sensitive to 660 management and changes in environment. 
663 Parts of this work was financed through the project: "Terrestrial C sequestration potential in Norway 664 under present and future climate (TerraC)" project no 184681/S30 financed by the Research Council 665 of Norway. We would also like to thank the Norwegian Institute of Bioeconomy Research (NIBIO) for 666 providing access to the forest soil database and Johannes Breidenbach (NIBIO) for discussing area 667 uncertainties. We also want to thank the numerous people that have dug, described and sampled 668 the soil profiles and the Norwegian Meteorological Institute for providing the climate data.

669

670

671

672

673

674

675

676

677

678

679

680

681

682

683

684

685

686

687

688

689

690

691

692

693

694

695

696

697

Reference List

Agriculture Canada Expert Committee on Soil Survey. 1987. The Canadian system of soil classification. 2 ed. Agric. Can. Publ. 1646. 164pp. pp. 164.

Aune, B. 1993. Temperature normals for the period 1961-1990. The Norwegian Meteorological Institute.

Baritz, R., Seufert, G., Montanarella, L., and Van Ranst, E. 2010. Carbon concentrations and stocks in forest soils of Europe. Forest Ecology and Management 260(3): 262-277. doi: 10.1016/j.foreco.2010.03.025.

Bradshaw, C.J.A., and Warkentin, I.G. 2015. Global estimates of boreal forest carbon stocks and flux. Global and Planetary Change 128: 24-30. doi: 10.1016/j.gloplacha.2015.02.004.

Callesen, I., Liski, J., Raulund-Rassmussen, K., Olsson, M., Strand, L.T., Vesterdal, L., and Westman, C.J. 2003. Soil carbon stores in Nordic well-drained forest soils - relationships with climate and texture class. Global Change Biology 9 (3): 358-371.

Callesen, I., Raulund-Rasmussen, K., Westman, C.J., and Strand, L.T. 2007. Nitrogen pools and C:N ratios in well-drained Nordic forest soils related to climate and soil texture. Boreal Environment Research 12: 681-692.

Callesen, I., Stupak, I., Georgiadis, P., Johannsen, V.K., Østergaard, H.S., and Vesterdal, L. 2015. Soil carbon stock change in the forests of Denmark between 1990 and 2008. Geoderma Regional 5: 169180. doi: http://dx.doi.org/10.1016/i.geodrs.2015.06.003.

Davidson, E.A., and Janssens, I.A. 2006. Temperature sensitivity of soil carbon decomposition and feedbacks to climate change. Nature 440(7081): 165-173.

De Vos, B., Cools, N., Ilvesniemi, H., Vesterdal, L., Vanguelova, E., and Camicelli, S. 2015. Benchmark values for forest soil carbon stocks in Europe: Results from a large scale forest soil survey. Geoderma 251: 33-46. doi: 10.1016/j.geoderma.2015.03.008.

de Wit, H.A., Austnes, K., Hylen, G., and Dalsgaard, L. 2015. A carbon balance of Norway: terrestrial and aquatic carbon fluxes. Biogeochemistry 123(1-2): 147-173. doi: 10.1007/s10533-014-0060-5. 
698

de Wit, H.A., and Kvindesland, S. 1999. Carbon stocks in Norwegian forest soils and effects of forest management on carbon storage.

Deluca, T.H., and Boisvenue, C. 2012. Boreal forest soil carbon: distribution, function and modelling. Forestry 85(2): 161-184. doi: 10.1093/forestry/cps003.

Esser, J.M., and Nyborg. 1992. Jordsmonn i barskog - en oversikt for Norge. Norwegian Institute of Land Inventory.

FAO Unesco. 1990. FAO/Unesco Soil Map of the World Revised Legend. ISRIC Wagningen.

Forland, E.J. 1993. Precipitation normals for the period 1961-1990. The Norwegian Meteorological Institute.

Frosterus, B. 1923. Förslag från kommitten før nomenklatur of klassifikasjon av jordartar og jordmåner. Beretning om Nordisk Jorbruksforskares forenings annen Kongres,. In Nordisk Jorbruksforskare Forening, Goethenborg, Sweden.

Goodale, C.L., Apps, M.J., Birdsey, R.A., Field, C.B., Heath, L.S., Houghton, R.A., Jenkins, J.C., Kohlmaier, G.H., Kurz, W., Liu, S.R., Nabuurs, G.J., Nilsson, S., and Shvidenko, A.Z. 2002. Forest carbon sinks in the Northern Hemisphere. Ecological Applications 12(3): 891-899.

Granhus, A., Hylen, G., and Nilsen, J.-E.Ø. 2012. Statistics of Forest Conditions and Resources in Norway. Norwegian Forest Research Institute. 03/2012.

Grossman, R.B., Harms, D.S., Kingsbury, D.F., Shaw, R.K., and Jenkins, A.B. 2001. Assesment of Soil Organic Carbon Using the U.S. Soil Survey. In Assesment methods for soil carbon. Edited by R. Lal and J.M. Kimble and R.F. Follett and B.A. Stewart. CRC Press. pp. 87-104.

Guo, Y.Y., Amundson, R., Gong, P., and Yu, Q. 2006. Quantity and spatial variability of soil carbon in the conterminous United States. Soil Science Society of America Journal 70(2): 590-600.

Honeysett, J.L., and Ratkowsky, D.A. 1989. The Use of Ignition Loss to Estimate Bulk-Density of Forest Soils. Journal of Soil Science 40(2): 299-308.

Jandl, R., Lindner, M., Vesterdal, L., Bauwens, B., Baritz, R., Hagedorn, F., Johnson, D.W., Minkkinen, K., and Byrne, K.A. 2007. How strongly can forest management influence soil carbon sequestration? Geoderma 137(3-4): 253-268. doi: 10.1016/j.geoderma.2006.09.003.

Johnson, K.D., Harden, J., McGuire, A.D., Bliss, N.B., Bockheim, J.G., Clark, M., NettletonHollingsworth, T., Jorgenson, M.T., Kane, E.S., Mack, M., O'Donnell, J., Ping, C.-L., Schuur, E.A.G., Turetsky, M.R., and Valentine, D.W. 2011. Soil carbon distribution in Alaska in relation to soilforming factors. Geoderma 167-68: 71-84. doi: 10.1016/j.geoderma.2011.10.006.

Karhu, K., Wall, A., Vanhala, P., Liski, J., Esala, M., and Regina, K. 2011. Effects of afforestation and deforestation on boreal soil carbon stocks-Comparison of measured $C$ stocks with Yasso07 model results. Geoderma 164(1-2): 33-45. doi: 10.1016/j.geoderma.2011.05.008.

Kjonaas, O.J., Aalde, H., Dalen, L.S., De Wit, H.A., Eldhuset, T., and Øyen, B.H. 2000. Carbon stocks in Norwegian forested systems. Preliminary data. Biotechnologie, Agronomie, Societe et Environnement 4(4): 311-314. 
735 Kleja, D.B., Svensson, M., Majdi, H., Jansson, P.-E., Langvall, O., Bergkvist, B., Johansson, M.-B., 736 Weslien, P., Truusb, L., Lindroth, A., and Agren, G.I. 2008. Pools and fluxes of carbon in three Norway 737 spruce ecosystems along a climatic gradient in Sweden. Biogeochemistry 89(1): 7-25. doi:

738 10.1007/s10533-007-9136-9.

739 Laiho, R., Penttila, T., and Laine, J. 2004. Variation in soil nutrient concentrations and bulk density 740 within peatland forest sites. Silva Fennica 38(1): 29-41.

741 Liski, J., Perruchoud, D., and Karjalainen, T. 2002. Increasing carbon stocks in the forest soil of 742 western Europe. Forest Ecology \& Management 169: 159-175.

743 Liski, J., and Westman, C.J. 1995. Density of organic carbon in soil at conferous forest sites in 744 southern Finland. Biogeochemistry 29: 183-197.

745 Liski, J., and Westman, C.J. 1997. Carbon storage in forerst soil of Finland 2. Size and regional 746 patterns. Biogeochemistry 36: 261-274.

747 Lorenz, M. 1995. International Co-operative programme on assessment and monitoring of air 748 pollution effects on forests -ICP forests Water Air and Soil Pollution 85(3): 1221-1226.

749 Lundstrom, U.S., van Breemen, N., Bain, D.C., van Hees, P.A.W., Giesler, R., Gustafsson, J.P., 750 Ilvesniemi, H., Karltun, E., Melkerud, P.A., Olsson, M., Riise, G., Wahlberg, O., Bergelin, A., Bishop, K., 751 Finlay, R., Jongmans, A.G., Magnusson, T., Mannerkoski, H., Nordgren, A., Nyberg, L., Starr, M., and 752 Strand, L.T. 2000. Advances in understanding the podzolization process resulting from a 753 multidisciplinary study of three coniferous forest soils in the Nordic Countries. Geoderma 94(2-4): 754 335-353.

Luyssaert, S., Ciais, P., Piao, S.L., Schulze, E.D., Jung, M., Zaehle, S., Schelhaas, M.J., Reichstein, M., Churkina, G., Papale, D., Abril, G., Beer, C., Grace, J., Loustau, D., Matteucci, G., Magnani, F., Nabuurs, G.J., Verbeeck, H., Sulkava, M., van der Werf, G.R., and Janssens, I.A. 2010. The European carbon balance. Part 3: forests. Global Change Biology 16(5): 1429-1450.

Melvin, A.M., Mack, M.C., Johnstone, J.F., McGuire, A.D., Genet, H., and Schuur, E.A.G. 2015. Differences in Ecosystem Carbon Distribution and Nutrient Cycling Linked to Forest Tree Species Composition in a Mid-Successional Boreal Forest. Ecosystems 18(8): 1472-1488. doi: 10.1007/s10021-015-9912-7.

Nilsen, P., and Strand, L.T. 2008. Thinning intensity effects on carbon and nitrogen stores and fluxes in a Norway spruce (Picea abies (L.) Karst.) stand after 33 years. Forest Ecology and Management 256(3): 201-208.

Nilsen, P., and Strand, L.T. 2013. Carbon stores and fluxes in even- and uneven-aged Norway spruce stands. Silva Fennica 47(4). doi: 10.14214/sf.1024.

Norwegian Environment Agency, S.N., Norwegian Institute of Bioeconomy Research. 2015. Greenhouse Gas Emissions 1990-2013, National Inventory Report

770 Summary -. The Norwegian Environment Agency. M-422.

771 Olsson, M.T., Erlandsson, M., Lundin, L., Nilsson, T., Nilsson, A., and Stendahl, J. 2009. Organic

772 Carbon Stocks in Swedish Podzol Soils in Relation to Soil Hydrology and Other Site Characteristics.

773 Silva Fennica 43(2): 209-222. doi: 10.14214/sf.207. 
774 R Development Core Team. 2010. R: A language and environment for statistical computing. R 775 Foundation for Statistical Computing, Vienna, Austria. .

776 SAS Institute. 1990. SAS User's Guide: Statistics. SAS Institute Inc., Cary, NC, USA.

Schimel, D.S., House, J.I., Hibbard, K.A., Bousquet, P., Ciais, P., Peylin, P., Braswell, B.H., Apps, M.J., Baker, D., Bondeau, A., Canadell, J., Churkina, G., Cramer, W., Denning, A.S., Field, C.B., Friedlingstein, P., Goodale, C., Heimann, M., Houghton, R.A., Melillo, J.M., Moore, B., III, Murdiyarso, D., Noble, I., Pacala, S.W., Prentice, I.C., and Raupach, M.R. 2001. Recent patterns and mechanisms of carbon exchange by terrestrial ecosystems. Nature (London) 414(6860): 169-172.

Schulze, E.D., Lloyd, J., Kelliher, F.M., Wirth, C., Rebmann, C., Lühker, B., Mund, M., Knohl, A., Milyukova, I.M., Schulze, W., Ziegler, W., Varlagin, A.B., Sogachev, A.F., Valentini, R., Dore, S., Grigoriev, S., Kolle, O., Panfyorov, M.I., Tchebakova, N., and Vygodskaya, N.N. 1999. Productivity of foresets in the Eurosiberian boreal region and their potential to act as a carbon sink - a synthesis. Global Change Biology 5 703-722.

Sft. 2006. Overvåkning av langtransportert luft og nedbør. Atmosfæriske tilførsler, 2005. (The Norwegian monitoring programme for long-range transported air pollutants. Results 2005). Statlig program for forurensningsovervåkning.

790 Shaw, C.H., Banfield, E., and Kurz, W.A. 2008. Stratifying soils into pedogenically similar categories for modeling forest soil carbon. Canadian Journal of Soil Science 88(4): 501-516.

Soil Survey Staff. 1999. Soil Taxonomy, A Basic System for of Soil Classifiation for Making and Interpreting Soil Surveys. United States Department of Agriculture, Natural Resources Conservation 796 Service.

Strand, L.T., Haaland, S., Kaste, O., and Stuanes, A.O. 2008. Natural variability in soil and runoff from small headwater catchments at Storgama, Norway. Ambio 37(1): 18-28. Journal 73(5): 1724-1732. doi: 10.2136/sssaj2008.0413.

802 Sveistrup, T.E. 1984. Retningslinjer for beskrivelse av jordprofil (Guideline for soil profile description) 803 in Norwegian. Jord og Myr 8(2): 47.

804 Tan, Z.X., Lal, R., Smeck, N.E., and Calhoun, F.G. 2004. Relationships between surface soil organic 805 carbon pool and site variables. Geoderma 121(3-4): 187-195.

806 Tarnocai, C. 1998. The amount of organic carbon in various soil orders and ecological provinces in 807 Canada. 
811 Turetsky, M.R., Bond-Lamberty, B., Euskirchen, E., Talbot, J., Frolking, S., McGuire, A.D., and Tuittila, 812 E.S. 2012. The resilience and functional role of moss in boreal and arctic ecosystems. New 813 Phytologist 196(1): 49-67. doi: 10.1111/j.1469-8137.2012.04254.x.

814 Van Cleve, K., and Powers, R.F. 1995. Soil Carbon, Soil Formation, and Ecosystem Development. In 815 Carbon Forms and Functions in Forest Soils. Edited by W.W. McFee and J.M. Kelly. SSSA, Madison, 816 WI. pp. 155-200.

817 Vejre, H., Callesen, I., Vesterdal, L., and Raulund-Rasmussen, K. 2003. Carbon and Nitrogen in Danish 818 Forest Soils -Contents and Distribution Determined by Soil Order. Soil Science Society of America 819 Journal 67 335-343.

820 WRB, I.W.G. 2015. World reference base for soil resources 2014, update 2015. International 821 classification system for naming soils and creating legends forsoil maps. FAO. 106. 
Table 1: Soils of the Norwegian forest soil database grouped according to the dominating process influencing $\mathrm{C}$ stocks and Canadian soil classification and World Reference Base (WRB) reference soil group equivalents.

\begin{tabular}{|c|c|c|c|c|c|c|}
\hline \multirow{2}{*}{$\begin{array}{l}\text { Stratification of soils } \\
\text { used in this study }\end{array}$} & \multirow{2}{*}{$\begin{array}{c}\text { Dominating } \\
\text { process }\end{array}$} & \multicolumn{4}{|c|}{ Canadian soil classification $\not$} & \multirow{2}{*}{$\begin{array}{r}\text { Equivalent } \\
\text { WRB } \\
\text { RSG }+\end{array}$} \\
\hline & & Order & Great group & $\mathrm{N}$ & Sub groups & \\
\hline Non soils $¥$ & Drought-root restriction, soil $<10 \mathrm{~cm}$ & Non-soil & & 28 & & Leptosol \\
\hline \multirow[t]{2}{*}{ Gleysolic } & Water saturation & Gleysolic & Gleysol & 61 & Orthic, Rego, Fero & Gleysol \\
\hline & & & Humic & 34 & Orthic, Rego & Podzol \\
\hline \multirow[t]{3}{*}{ Podzolic - self drained } & Podzolization & Podzolic & Ferro-Humic & 75 & Orthic, Sombric, Orthstein & Podzol \\
\hline & & & Humo-Ferric & 307 & Orthic, Sombric, Orthstein & Podzol \\
\hline & & & Humic & 9 & Orthic & Podzol \\
\hline \multirow[t]{2}{*}{ Podzolic - gleyed } & Podzolization/water saturation & & Ferro-Humic & 16 & Gleyed, Gleyed Sombric, Gleyed Orthstein & Podzol \\
\hline & & & Humo-Ferric & 79 & Gleyed, Gleyed Sombric, Gleyed Orthstein & Podzol \\
\hline \multirow[t]{4}{*}{ Brunisolic - self drained } & Brunification & Brunisolic & Dystric & 27 & Orthic, Duric, & Cambisol \\
\hline & & & Eutric & 5 & Orthic & Cambisol \\
\hline & & & Melanic & 2 & Orthic & Cambisol \\
\hline & & & Sombric & 25 & Orthic & Cambisol \\
\hline \multirow[t]{2}{*}{ Brunisolic - eluviated } & Podzolization & & Dystric & 76 & Eluviated & Arenosol \\
\hline & & & Sombric & 4 & Eluviated & Cambisol \\
\hline \multirow[t]{3}{*}{ Brunisolic - gleyed } & Water saturation/brunification/ & & Dystric & 33 & Gleyed Eluviated, Gleyed, & Cambisol \\
\hline & podzolization & & Eutric & 1 & Gleyed Eluviated & Cambisol \\
\hline & & & Sombric & 6 & Gleyed, Gleyed Eluviated & Cambisol \\
\hline \multirow[t]{2}{*}{ Regosolic } & Drought/water saturation/ & Regosolic & Humic & 29 & Orthic, Gleyed & Rego-/Fluvi-/Leptosol \\
\hline & root restriction/shallow soils & & Regosol & 66 & Orthic, Gleyed & Rego-/Fluvi-/Leptosol \\
\hline Organic - folisols & Drought - root restriction/shallow soils & Organic & Folisol & 51 & Hemic,Humic, Histic & Histosol \\
\hline \multirow[t]{3}{*}{ Organic - wet } & Water saturation & & Fibrisol & 13 & Typic, Terric, Mesic, Humic & Histosol \\
\hline & & & Mesisol & 30 & Terric, Typic, Humic & Histosol \\
\hline & & & Hemisol & 63 & Terric, Typic, Fibric & Histosol \\
\hline
\end{tabular}

\. The distribution of soil profiles is given on Great group level and the Subgroups for each great group are listed ranked according to the most frequently occurring. + Reference Soil Group.

$\ddagger$ Non-soils are soils less than $10 \mathrm{~cm}$ deep 
Table 2. Classification, horizon designations, profile depths, carbon and nitrogen stocks, and $\mathrm{C} / \mathrm{N}$ ratio of the forest floor of the ten soil individual profiles picked out from the Norwegian forest soil database for the Monte Carlo simulation of uncertainties.

\begin{tabular}{|c|c|c|c|c|c|c|c|}
\hline Profile representative of & Canadian soil classification & Horizonst & $\begin{array}{r}\text { Profile depth } \\
(\mathrm{cm})\end{array}$ & $\begin{array}{r}\text { Organic } \\
\text { horizons } \\
(\mathrm{cm}) \\
\end{array}$ & $\begin{array}{r}\text { C stock } \\
C \mathrm{~kg} \mathrm{~m}^{-2}\end{array}$ & $\begin{array}{r}\mathrm{N} \text { stock } \\
\mathrm{N} \mathrm{kg} \mathrm{m}^{-2}\end{array}$ & $\begin{array}{r}\mathrm{C} / \mathrm{N} \text { ratio } \\
\text { in forest } \\
\text { floor }\end{array}$ \\
\hline Non-soils $<10 \mathrm{~cm}$ & Non soil & LFH, R & 8 & 8 & 1.40 & 0.05 & \\
\hline Gleysolic & Orthic Humic Gleysol & LFH, Ah, Bg, Cgj & 75 & 9 & 17.84 & 0.99 & 22 \\
\hline Podzolic - self-drained & Orthic Humoferric Podzol & $\mathrm{LFH}, \mathrm{Ae}, \mathrm{Bf1}, \mathrm{Bf2}, \mathrm{BC}$ & 58 & 8 & 15.14 & 0.60 & 28 \\
\hline Podzolic - gleyed & Gleyed Humoferric Podzol & LFH, Ae, Bf, Cgj, Cg & 85 & 12 & 18.48 & 0.92 & 34 \\
\hline Brunisolic - self-drained & Orthic Sombric Brunisol & $\mathrm{LFH}, \mathrm{Ah}, \mathrm{Bm}, \mathrm{C}$ & 42 & 9 & 13.42 & 0.52 & 31 \\
\hline Brunisolic - eluviated & Eluviated Dystric Brunisol & LFH, Ae, Bf, BC, C & 90 & 6 & 12.10 & 0.27 & 40 \\
\hline Brunisolic - gleyed & Gleyed Dystric Brunisol & LFH, Ahej, Bf, BC, Cgj & 70 & 10 & 15.52 & 0.53 & 38 \\
\hline Regosolic & Orthic Regosol & $\mathrm{LFH}, \mathrm{Ae}, \mathrm{R}$ & 32 & 17 & 10.77 & 0.42 & 27 \\
\hline Organic - folisols & Hemic Folisol & LFH, R & 13 & 13 & 8.81 & 0.26 & 34 \\
\hline Organic-wet & Terric Humisol & Of1, of2, Oh, Om, C & 70 & 65 & 30.42 & 0.70 & \\
\hline
\end{tabular}

† Description of the horizon designations: The organic horizons(>17\% organic C): L- litter, $\mathrm{F}$ - fragmented partly decomposed, $\mathrm{H}$ - humified, well decomposed , $\mathrm{O}$-peat of either, f-fibric, $\mathrm{m}$ mesic or $h$ - humic material. The mineral soil A, B, C, horizons with suffices $h$-organic matter enrichment, e -eluviation, $f$-enrichment with amorphic material: organic matter, Al and Fe, $g$ gleyed, $\mathrm{m}$-weathered, $\mathrm{j}$-modifier of weak and inadequate expression of a suffix, The $\mathrm{R}$ - indicates bedrock. 
Table 3 Total $\mathrm{C}$ stocks and percentage of $\mathrm{C}$ stocks in mineral soil grouped according to Canadian soil orders and soil water related properties. Lower case letters show significant $(\alpha \sim 0.05)$ differences between the soil groups tested.

\begin{tabular}{|c|c|c|c|c|c|c|c|c|c|c|c|}
\hline & & \multirow[b]{2}{*}{$\mathrm{N}$} & \multirow[b]{2}{*}{$\%$} & \multicolumn{4}{|c|}{ C stock kg C m${ }^{-2}$} & \multicolumn{4}{|c|}{$\% \mathrm{C}$ in mineral soil } \\
\hline & & & & mean & median & $\mathrm{ICL}^{+}$ & $\mathrm{uCL}+$ & mean & median & $\mathrm{ICL}^{\dagger}$ & $\mathrm{uCL}+$ \\
\hline Non-soils & & 28 & 3 & $1.62 \mathrm{e}$ & 1.4 & -1.8 & 5.0 & - & - & - & - \\
\hline Gleysolic & & 95 & 9 & $19.33 b$ & 17.8 & 17.5 & 21.2 & $41 \mathrm{~cd}$ & 34 & 36 & 46 \\
\hline \multirow[t]{2}{*}{ Podzolic } & - self-drained & 391 & 38 & $15.46 \mathrm{bc}$ & 14.1 & 14.6 & 16.4 & $60 a$ & 63 & 58 & 62 \\
\hline & - gleyed & 95 & 9 & $18.41 b$ & 18.3 & 16.6 & 20.3 & $61 a$ & 64 & 57 & 66 \\
\hline \multirow[t]{3}{*}{ Brunisolic } & - self-drained & 59 & 6 & $15.87 \mathrm{bc}$ & 13.4 & 13.5 & 18.2 & $46 \mathrm{bcd}$ & 52 & 40 & 52 \\
\hline & - eluviated & 80 & 8 & $12.06 \mathrm{~cd}$ & 10.8 & 10.0 & 14.1 & $47 b c$ & 48 & 42 & 52 \\
\hline & - gleyed & 40 & 4 & $14.12 \mathrm{~cd}$ & 12.7 & 11.3 & 17.0 & $52 b$ & 49 & 45 & 59 \\
\hline Regosolic & & 95 & 9 & $11.11 \mathrm{~d}$ & 9.5 & 9.3 & 13.0 & $36 d$ & 33 & 32 & 41 \\
\hline \multirow[t]{2}{*}{ Organic } & - folisols & 51 & 5 & $10.26 \mathrm{~d}$ & 8.8 & 7.7 & 12.8 & - & - & - & - \\
\hline & - wet & 106 & 10 & $31.32 \mathrm{a}$ & 30.5 & 29.6 & 33.1 & - & - & - & - \\
\hline
\end{tabular}

+ ICL lower confidence limit, $\mathrm{uCL}$ upper confidence limit, given as $95 \%$ of the least significant mean. 
Table 4 Nitrogen stocks and C:N ratio in forest floor grouped according to Canadian soil orders and soil water related properties. Lower case letters show significant $(\alpha \sim 0.05)$ differences between the soil groups tested.

\begin{tabular}{|c|c|c|c|c|c|c|c|c|c|c|}
\hline & & \multirow[b]{2}{*}{$\mathrm{N}$} & \multicolumn{4}{|c|}{$\mathrm{N}$ stock $\mathrm{kg} \mathrm{N} \mathrm{m}^{-2}$} & \multicolumn{4}{|c|}{$\mathrm{C}: \mathrm{N}$ ratio forest floor } \\
\hline & & & mean & median & $\mathrm{ICL}+$ & $\mathrm{uCL}+$ & mean & median & $\mathrm{ICL}+$ & $\mathrm{uCL}+$ \\
\hline Non-soils & & 28 & $0.06 \mathrm{~h}$ & 0.04 & -0.08 & 0.20 & - & - & - & - \\
\hline Gleysolic & & 95 & $0.78 b$ & 0.71 & 0.71 & 0.86 & $29 c$ & 26 & 27 & 30 \\
\hline \multirow[t]{2}{*}{ Podzolic } & - self-drained & 391 & 0.59cde & 0.51 & 0.54 & 0.62 & $30 c$ & 29 & 29 & 31 \\
\hline & - gleyed & 95 & $0.70 \mathrm{bc}$ & 0.64 & 0.62 & 0.77 & $30 c$ & 29 & 28 & 31 \\
\hline \multirow[t]{3}{*}{ Brunisolic } & - self-drained & 59 & $0.65 \mathrm{bcd}$ & 0.57 & 0.55 & 0.75 & $28 c$ & 27 & 26 & 30 \\
\hline & - eluviated & 80 & $0.41 \mathrm{fg}$ & 0.38 & 0.32 & 0.49 & $36 a$ & 35 & 34 & 38 \\
\hline & - gleyed & 40 & $0.51 \mathrm{def}$ & 0.40 & 0.40 & 0.63 & $33 b$ & 36 & 30 & 36 \\
\hline Regosolic & & 95 & $0.43 \mathrm{efg}$ & 0.34 & 0.36 & 0.51 & $29 c$ & 28 & 27 & 31 \\
\hline \multirow[t]{2}{*}{ Organic } & - folisols & 51 & $0.34 \mathrm{~g}$ & 0.28 & 0.23 & 0.44 & - & - & - & - \\
\hline & - wet & 106 & $1.10 a$ & 1.00 & 1.03 & 1.17 & - & - & - & - \\
\hline
\end{tabular}

+ICL lower confidence limit, uCL upper confidence limit, given as $95 \%$ of the least significant mean. 
Table 5 The Monte Carlo simulation based on typical soil profiles according to Canadian soil classification (orders and selected subgroup), standard deviation for each simulation are written in brackets.

\begin{tabular}{|c|c|c|c|c|c|c|c|}
\hline & & \multicolumn{6}{|c|}{ C stocks $\left(\mathrm{kg} \mathrm{C} \mathrm{m}^{-2}\right)$ from Mont Carlo simulation ${ }^{\dagger}$} \\
\hline & & \multicolumn{3}{|c|}{ CF uniform distribution } & \multicolumn{3}{|c|}{ CF mid-class from field } \\
\hline & & BD5 & BD10 & BD20 & BD5 & BD10 & BD20 \\
\hline Non-soils & & $1.4(0.1)$ & $1.4(0.2)$ & $1.4(0.3)$ & $1.4(0.1)$ & $1.4(0.2)$ & $1.4(0.3)$ \\
\hline Gleysolic & & $17.8(1.6)$ & $17.8(2.2)$ & $17.8(3.8)$ & $18.6(1.1)$ & $18.6(1.9)$ & 18.6(3.7) \\
\hline \multirow[t]{2}{*}{ Podzolic } & - self-drained & $15.1(1.2)$ & $15.1(1.8)$ & $15.1(3.2)$ & $15.4(0.9)$ & $15.4(1.6)$ & $15.4(3.1)$ \\
\hline & - gleyed & $18.5(1.3)$ & $18.5(2.1)$ & $18.5(3.8)$ & $18.5(1.1)$ & $18.5(2.0)$ & 18.5(3.7) \\
\hline \multirow[t]{3}{*}{ Brunisolic } & - self-drained & $13.4(1.1)$ & $13.4(1.7)$ & $13.4(2.9)$ & $14.3(0.8)$ & $14.3(1.5)$ & $14.3(2.9)$ \\
\hline & - eluviated & $12.1(1.0)$ & $12.1(1.4)$ & $12.1(2.4)$ & $12.3(0.8)$ & $12.3(1.3)$ & $12.2(2.4)$ \\
\hline & - gleyed & $15.5(1.3)$ & $15.5(1.9)$ & $15.5(3.2)$ & $16.0(1.0)$ & $16.0(1.7)$ & $16.0(3.2)$ \\
\hline Regosolic & & $10.8(0.7)$ & $10.8(1.2)$ & $10.8(2.2)$ & $10.8(0.7)$ & $10.8(1.2)$ & $10.8(2.2)$ \\
\hline \multirow[t]{2}{*}{ Organic } & - folisols & $8.8(0.6)$ & $8.8(1.0)$ & $8.8(1.8)$ & $8.8(0.6)$ & $8.8(1.0)$ & $8.8(1.8)$ \\
\hline & - wet & $30.4(1.9)$ & $30.4(3.0)$ & $30.5(6.2)$ & $30.4(1.9)$ & $30.4(3.3)$ & $30.5(6.2)$ \\
\hline
\end{tabular}

tThe Monte Carlo simulations were run on combinations of three different error estimates for bulk density (BD) 5,10 or $20 \%$ (BD5, BD10 and BD20) and coarse fraction (CF) estimates based on either a uniform distribution or the mid-class from field registration. 
Table 6. Relationships between some climate parameters and total $\mathrm{C}$ and $\mathrm{N}$ stocks, $\mathrm{C}$ stocks and $\mathrm{C}: \mathrm{N}$ ratios of the forest floor, and the proportion of $\mathrm{C}$ stock stored in the mineral soil compartment for the different Norwegian forest soil types. Only statistical significant $(p<0.05)$ spearman correlation coefficients are listed in the table.

\begin{tabular}{|c|c|c|c|c|c|c|c|c|c|c|c|}
\hline & & 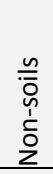 & 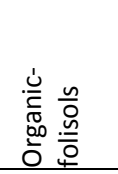 & 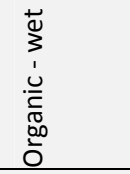 & $\begin{array}{l}\frac{u}{\overline{0}} \\
\frac{\mathrm{n}}{\bar{u}} \\
\frac{\mathrm{u}}{0}\end{array}$ & 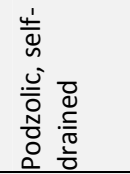 & 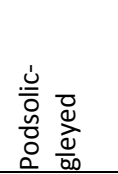 & 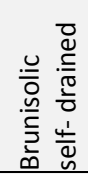 & 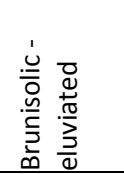 & 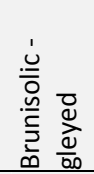 & 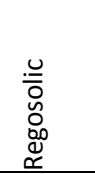 \\
\hline $\begin{array}{l}\text { MAT } \\
\text { (C }\end{array}$ & $\begin{array}{l}\text { Tot-C }\left(\mathrm{kg} \mathrm{C} \mathrm{m}^{-2}\right) \\
\text { Tot- }\left(\mathrm{kg} \mathrm{N} \mathrm{m}^{-2}\right) \\
\mathrm{C} \text {-forest floor }\left(\mathrm{kg} \mathrm{C} \mathrm{m}^{-2}\right) \\
\mathrm{C}: \mathrm{N} \text { ratio forest floor } \\
\mathrm{C} \% \text { in mineral soil }\end{array}$ & & $\begin{array}{l}0.28^{*} \\
0.36^{* *}\end{array}$ & $\begin{array}{l}-0.36 * * * \\
-0.38 * * *\end{array}$ & $0.20 *$ & $\begin{array}{l}0.32 * * * \\
0.34 * * * \\
0.20^{* * *} \\
-0.24 * * *\end{array}$ & $\begin{array}{l}0.57 * * * \\
0.49 * * * \\
0.31 * *\end{array}$ & & & $-0.37^{*}$ & \\
\hline $\begin{array}{l}\text { MAP } \\
(\mathrm{mm})\end{array}$ & $\begin{array}{l}\text { Tot-C }\left(\mathrm{kg} \mathrm{C} \mathrm{m}^{-2}\right) \\
\text { Tot- }\left(\mathrm{kg} \mathrm{N} \mathrm{m}^{-2}\right) \\
\mathrm{C} \text {-forest floor }\left(\mathrm{kg} \mathrm{C} \mathrm{m}^{-2}\right) \\
\mathrm{C}: \mathrm{N} \text { ratio forest floor } \\
\mathrm{C} \% \text { in mineral soil }\end{array}$ & & $\begin{array}{l}0.29^{*} \\
0.46^{* * *}\end{array}$ & & & $\begin{array}{l}0.28 * * * \\
0.32 * * * \\
0.12 * \\
-0.33^{* * *} \\
0.14 * * \\
\end{array}$ & $\begin{array}{l}0.43 * * * \\
0.30 * * \\
0.35 * * *\end{array}$ & & $\begin{array}{l}0.25^{*} \\
0.25^{*} \\
-0.33^{* * *}\end{array}$ & & \\
\hline $\begin{array}{l}\text { Growing season } \\
\left(\Sigma \text { days }>5^{\circ} \mathrm{C}\right)\end{array}$ & $\begin{array}{l}\text { Tot-C }\left(\mathrm{kg} \mathrm{C} \mathrm{m}^{-2}\right) \\
\text { Tot- }\left(\mathrm{kg} \mathrm{N} \mathrm{m}^{-2}\right) \\
\mathrm{C} \text {-forest floor }\left(\mathrm{kg} \mathrm{C} \mathrm{m}^{-2}\right) \\
\mathrm{C}: \mathrm{N} \text { ratio forest floor } \\
\mathrm{C} \% \text { in mineral soil }\end{array}$ & & $\begin{array}{l}0.34^{*} \\
0.35^{*}\end{array}$ & $\begin{array}{l}-0.30^{* *} \\
-0.31^{* *}\end{array}$ & & $\begin{array}{l}0.26^{* * *} \\
0.29^{* * *} \\
0.20^{* * *} \\
-0.12^{*}\end{array}$ & $\begin{array}{l}0.42 * * * \\
0.35^{* *}\end{array}$ & & & & \\
\hline $\begin{array}{l}\text { Altitude } \\
\text { ( } \mathrm{m} \text { above sea level) }\end{array}$ & $\begin{array}{l}\text { Tot-C }\left(\mathrm{kg} \mathrm{C} \mathrm{m}^{-2}\right) \\
\text { Tot- }\left(\mathrm{kg} \mathrm{N} \mathrm{m}^{-2}\right) \\
\mathrm{C} \text {-forest floor }\left(\mathrm{kg} \mathrm{C} \mathrm{m}^{-2}\right) \\
\mathrm{C}: \mathrm{N} \text { ratio forest floor } \\
\mathrm{C} \% \text { in mineral soil }\end{array}$ & & & $0.21 *$ & $-0.25 *$ & $\begin{array}{l}-0.12^{*} \\
-0.12^{*} \\
0.12^{*}\end{array}$ & & & & $0.37^{*}$ & $-0.23 *$ \\
\hline
\end{tabular}


Table 7. Relationships between some forest and vegetation parameters and total $\mathrm{C}$ and $\mathrm{N}$ stocks, $\mathrm{C}$ stocks and $\mathrm{C}: \mathrm{N}$ ratios of the forest floor, and the proportion of $C$ stock stored in the mineral soil compartment for the different Norwegian forest soil types. Only statistical significant $(p<0.05)$ spearman correlation coefficients are listed in the table.

\begin{tabular}{|c|c|c|c|c|c|c|c|c|c|c|c|}
\hline & & $\begin{array}{l}\frac{n}{\overline{0}} \\
0 \\
\frac{1}{0} \\
z\end{array}$ & 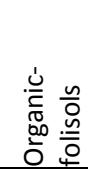 & 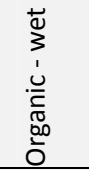 & 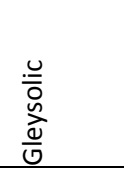 & 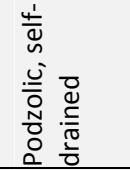 & 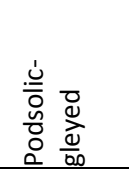 & 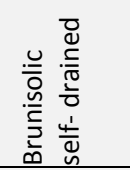 & 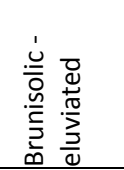 & 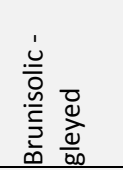 & 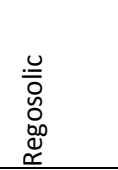 \\
\hline $\begin{array}{l}\text { Forest age } \\
\text { (y) }\end{array}$ & $\begin{array}{l}\text { Tot-C }\left(\mathrm{kg} \mathrm{C} \mathrm{m}^{-2}\right) \\
\text { Tot- } \mathrm{N}\left(\mathrm{kg} \mathrm{N} \mathrm{m}^{-2}\right) \\
\mathrm{C} \text {-forest floor }\left(\mathrm{kg} \mathrm{C} \mathrm{m}^{-2}\right) \\
\mathrm{C}: \mathrm{N} \text { ratio forest floor } \\
\mathrm{C} \% \text { in mineral soil }\end{array}$ & & & & & $\begin{array}{l}0.16^{* *} \\
0.25^{* * *} \\
0.30^{* * *} \\
-0.15^{*}\end{array}$ & $\begin{array}{l}0.45^{* * *} \\
0.41 * * \\
-0.38 * * \\
\end{array}$ & & & & $\begin{array}{l}-0.37 * * \\
0.40 * *\end{array}$ \\
\hline $\begin{array}{l}\text { Ground vegetation, } \\
\text { Moisture } \\
\text { (1=dry- 3=moist) }\end{array}$ & $\begin{array}{l}\text { Tot-C }\left(\mathrm{kg} \mathrm{C} \mathrm{m}^{-2}\right) \\
\text { Tot- }\left(\mathrm{kg} \mathrm{N} \mathrm{m}^{-2}\right) \\
\mathrm{C} \text {-forest floor }\left(\mathrm{kg} \mathrm{C}^{-2}\right) \\
\mathrm{C}: \mathrm{N} \text { ratio forest floor } \\
\mathrm{C} \% \text { in mineral soil }\end{array}$ & & & $0.24^{*}$ & $\begin{array}{l}0.55^{* * *} \\
0.52 * * * \\
0.42 * * * \\
-0.21 *\end{array}$ & $\begin{array}{l}0.15^{* *} \\
0.17^{* * *} \\
0.11^{*} \\
-0.22^{* * *}\end{array}$ & & & $\begin{array}{l}0.39 * * * \\
0.48 * * * \\
0.32 * * \\
-0.35 * *\end{array}$ & $\begin{array}{l}0.40^{* *} \\
0.34^{*}\end{array}$ & $\begin{array}{l}0.45 * * * \\
0.43 * * * \\
0.38 * * *\end{array}$ \\
\hline $\begin{array}{l}\text { Ground vegetation } \\
\text { Nutrient } \\
\text { (1= poor - 3=rich) }\end{array}$ & $\begin{array}{l}\text { Tot-C }\left(\mathrm{kg} \mathrm{C} \mathrm{m}^{-2}\right) \\
\text { Tot- }\left(\mathrm{kg} \mathrm{N} \mathrm{m}^{-2}\right) \\
\mathrm{C} \text {-forest floor }\left(\mathrm{kg} \mathrm{C}^{-2}\right) \\
\mathrm{C}: \mathrm{N} \text { ratio forest floor } \\
\mathrm{C} \% \text { in mineral soil }\end{array}$ & & $0.35^{*}$ & & $\begin{array}{l}-0.24 * \\
-0.39 * * * \\
-0.50 * * * \\
0.46 * * *\end{array}$ & $\begin{array}{l}-0.36 * * * \\
-0.53 * * * \\
0.42 * * *\end{array}$ & $\begin{array}{l}-0.49 * * * \\
-0.52 * * * \\
0.47^{* * *}\end{array}$ & $\begin{array}{l}-0.35^{* *} \\
-0.56 * * * \\
0.44^{* * *}\end{array}$ & $\begin{array}{l}0.23^{*} \\
-0.39 * * * \\
0.25^{*}\end{array}$ & $\begin{array}{l}0.45 * * \\
-0.34 * \\
-0.66 * * *\end{array}$ & $\begin{array}{l}0.29 * * \\
-0.48 * * *\end{array}$ \\
\hline $\begin{array}{l}\text { Forest stand maturity } \\
\text { (1= young }-5=\text { mature) }\end{array}$ & $\begin{array}{l}\text { Tot-C }\left(\mathrm{kg} \mathrm{C} \mathrm{m}^{-2}\right) \\
\text { Tot- }\left(\mathrm{kg} \mathrm{N} \mathrm{m}^{-2}\right) \\
\mathrm{C} \text {-forest floor }\left(\mathrm{kg} \mathrm{C} \mathrm{m}^{-2}\right) \\
\mathrm{C}: \mathrm{N} \text { ratio forest floor } \\
\mathrm{C} \% \text { in mineral soil }\end{array}$ & & & & & $\begin{array}{l}0.15^{* *} \\
0.15^{*} \\
0.17^{* *}\end{array}$ & $-0.28 *$ & & & & $-0.25 *$ \\
\hline $\begin{array}{l}\text { Site index } \\
(6-26)\end{array}$ & $\begin{array}{l}\text { Tot-C }\left(\mathrm{kg} \mathrm{C} \mathrm{m}^{-2}\right) \\
\text { Tot- }\left(\mathrm{kg} \mathrm{N} \mathrm{m}^{-2}\right) \\
\mathrm{C} \text {-forest floor }\left(\mathrm{kg} \mathrm{C} \mathrm{m}^{-2}\right) \\
\mathrm{C}: \mathrm{N} \text { ratio forest floor } \\
\mathrm{C} \% \text { in mineral soil }\end{array}$ & & & & $\begin{array}{l}-0.31^{*} \\
0.35^{*}\end{array}$ & $\begin{array}{l}0.21 * * * \\
-0.27 * * * \\
-0.44^{* * *} \\
0.28 * * *\end{array}$ & $0.25 *$ & $\begin{array}{l}-0.31^{*} \\
0.33^{*}\end{array}$ & & & $\begin{array}{l}0.31^{*} \\
-0.37^{* *}\end{array}$ \\
\hline
\end{tabular}


Table 8. Relationships between some hydrology and drainage related parameters with regard to total $\mathrm{C}$ and $\mathrm{N}$ stocks, $\mathrm{C}$ stocks and $\mathrm{C}: \mathrm{N}$ ratios of the forest floor, and the proportion of $\mathrm{C}$ stock stored in the mineral soil compartment for the different Norwegian forest soil types. Only statistical significant ( $<<0.05$ ) spearman correlation coefficients are listed in the table

\begin{tabular}{|c|c|c|c|c|c|c|c|c|c|c|c|}
\hline & & 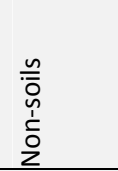 & 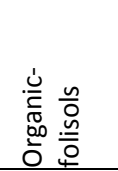 & 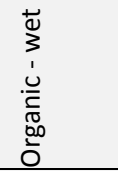 & $\begin{array}{l}\frac{u}{\overline{0}} \\
\frac{\mathrm{M}}{\mathrm{d}} \\
\frac{\mathrm{d}}{\mathrm{v}}\end{array}$ & 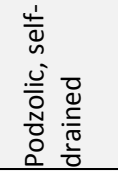 & 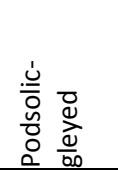 & 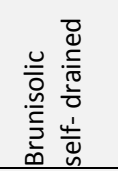 & 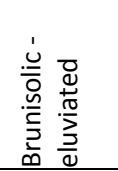 & 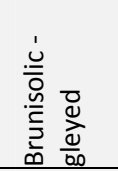 & 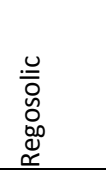 \\
\hline $\begin{array}{l}\text { Soils depth } \\
(\mathrm{cm})\end{array}$ & $\begin{array}{l}\text { Tot-C }\left(\mathrm{kg} \mathrm{C} \mathrm{m}^{-2}\right) \\
\text { Tot-N }\left(\mathrm{kg} \mathrm{N} \mathrm{m}^{-2}\right) \\
\mathrm{C} \text {-forest floor }\left(\mathrm{kg} \mathrm{C} \mathrm{m}^{-2}\right) \\
\mathrm{C}: \mathrm{N} \text { ratio forest floor } \\
\mathrm{C} \% \text { in mineral soil }\end{array}$ & $\begin{array}{l}0.66 * * * \\
0.73 * * * \\
0.70 * * *\end{array}$ & $\begin{array}{l}0.68 * * * \\
0.75 * * * \\
0.63 * * *\end{array}$ & $\begin{array}{l}0.77^{* * *} \\
0.69^{* * *}\end{array}$ & $\begin{array}{l}0.23^{*} \\
-0.21 * \\
0.33^{* *} \\
\end{array}$ & $\begin{array}{l}0.16 * * * \\
0.19 * * *\end{array}$ & $\begin{array}{l}0.22^{*} \\
0.31^{* *} \\
0.36^{* * *}\end{array}$ & $\begin{array}{l}0.42 * * \\
0.47 * * *\end{array}$ & $0.28 *$ & & $\begin{array}{l}0.47^{* * *} \\
0.54^{* * *}\end{array}$ \\
\hline $\begin{array}{l}\text { Drainage } \\
\text { (1=excessively well } \\
-13 \text { =very poor) }\end{array}$ & $\begin{array}{l}\text { Tot-C }\left(\mathrm{kg} \mathrm{C} \mathrm{m}^{-2}\right) \\
\text { Tot- }\left(\mathrm{kg} \mathrm{N} \mathrm{m}^{-2}\right) \\
\mathrm{C} \text {-forest floor }\left(\mathrm{kg} \mathrm{C} \mathrm{m}^{-2}\right) \\
\mathrm{C}: \mathrm{N} \text { ratio forest floor } \\
\mathrm{C} \% \text { in mineral soil }\end{array}$ & & $\begin{array}{l}0.49 * * * \\
0.50 * * * \\
0.38 *\end{array}$ & $\begin{array}{l}0.21 * \\
0.23^{*}\end{array}$ & $\begin{array}{l}0.30 * * \\
0.28 * * \\
0.39 * * * \\
-0.38 * * *\end{array}$ & $\begin{array}{l}0.18^{* * *} \\
0.17^{* * *}\end{array}$ & $\begin{array}{l}0.27^{* *} \\
0.25^{*} \\
0.22 *\end{array}$ & $0.30 *$ & $\begin{array}{l}0.49 * * * \\
0.43 * * * \\
0.40 * * * \\
-0.28 *\end{array}$ & $\begin{array}{l}0.36^{*} \\
0.57^{* * *} \\
-0.36^{*}\end{array}$ & $\begin{array}{l}0.31^{* *} \\
0.33^{* * *} \\
0.33^{* *}\end{array}$ \\
\hline $\begin{array}{l}\text { Depth to ground water } \\
(\mathrm{cm})\end{array}$ & $\begin{array}{l}\text { Tot-C }\left(\mathrm{kg} \mathrm{C} \mathrm{m}^{-2}\right) \\
\text { Tot- } \mathrm{N}\left(\mathrm{kg} \mathrm{N} \mathrm{m}^{-2}\right) \\
\mathrm{C}-\text { forest floor }\left(\mathrm{kg} \mathrm{C}^{-2}\right) \\
\mathrm{C}: \mathrm{N} \text { ratio forest floor } \\
\mathrm{C} \% \text { in mineral soil }\end{array}$ & & & & & $\begin{array}{l}0.28^{* * *} \\
0.27^{* * *}\end{array}$ & $0.25 *$ & $0.48^{* *}$ & $0.32 *$ & & \\
\hline
\end{tabular}


Table 9. Estimates of the total $\mathrm{C}$ stock and uncertainty given as gigaton ( $\mathrm{Gt} \mathrm{C}$ ) in Norwegian forest soils based on Ismean $\mathrm{C}$ stock and corresponding area for soil types present in the Norwegian soil forest database.

\begin{tabular}{|c|c|c|c|c|c|c|c|c|c|c|}
\hline & & \multirow[b]{2}{*}{$\%$ of soils } & \multirow[b]{2}{*}{ Area $\mathrm{km}^{2}$} & \multirow[b]{2}{*}{$\mathrm{CV}_{\text {Area }}{ }^{+}$} & \multirow[b]{2}{*}{$\mathrm{CV}_{\mathrm{SOC}} \ddagger$} & \multirow[b]{2}{*}{$\mathrm{CV}_{\text {Total }} \not \mathrm{R}$} & \multicolumn{4}{|c|}{ Gt C } \\
\hline & & & & & & & SD tot & C in soil & $\mathrm{ICL}$ & $\mathrm{uCl}$ \\
\hline Non-soils & $<10 \mathrm{~cm}$ & 3 & 3600 & $16.7 \%$ & $2.4 \%$ & $16.9 \%$ & 0.0010 & 0.006 & 0.004 & 0.008 \\
\hline Gleysolic & & 9 & 10800 & $9.9 \%$ & $1.2 \%$ & $10.0 \%$ & 0.0208 & 0.208 & 0.168 & 0.249 \\
\hline \multirow[t]{2}{*}{ Podzolic } & - self-drained & 38 & 45600 & $4.0 \%$ & $0.6 \%$ & $4.0 \%$ & 0.0283 & 0.707 & 0.652 & 0.762 \\
\hline & - gleyed & 9 & 10800 & $9.9 \%$ & $1.2 \%$ & $10.0 \%$ & 0.0199 & 0.199 & 0.160 & 0.237 \\
\hline \multirow[t]{3}{*}{ Brunisolic } & - self-drained & 6 & 7200 & $12.0 \%$ & $1.4 \%$ & $12.0 \%$ & 0.0138 & 0.114 & 0.088 & 0.141 \\
\hline & - eluviated & 8 & 9600 & $10.3 \%$ & $1.3 \%$ & $10.4 \%$ & 0.0121 & 0.116 & 0.093 & 0.140 \\
\hline & - gleyed & 4 & 4800 & $14.9 \%$ & $2.1 \%$ & $15.1 \%$ & 0.0103 & 0.068 & 0.048 & 0.088 \\
\hline Regosolic & & 9 & 10800 & $9.9 \%$ & $1.1 \%$ & $10.0 \%$ & 0.0121 & 0.121 & 0.097 & 0.145 \\
\hline \multirow[t]{2}{*}{ Organic } & - folisols & 5 & 6000 & $13.4 \%$ & $1.4 \%$ & $13.5 \%$ & 0.0083 & 0.062 & 0.046 & 0.078 \\
\hline & - wet & 10 & 12000 & $9.4 \%$ & $0.9 \%$ & $9.4 \%$ & 0.0367 & 0.389 & 0.317 & 0.460 \\
\hline
\end{tabular}

† Coefficient of variances connected to the area covered by the soil type, $¥$ Coefficient of variances connected to the mean C stocks of the soil type, $\not$ The combined CV based on the CVarea and CVsoc, ICL and UCL are the lower and upper $95 \%$ confidence limit 


\section{Figure captions:}

Figure 1. Map of Norway showing forested areas and the grid plots where the forest soils were described and sampled.

Figure 2. Carbon stock distribution by master horizon and dominant soil classification. Error bars confidence limit, given as $95 \%$ of the least significant mean for the horizon thickness and $\mathrm{C}$ stocks. The full line indicates the mineral soil surface; the dotted line indicates the average depth of the soil profiles.

Figure 3. Total carbon stocks of 488 in Norwegian Podzolic forest soils plotted against mean annual precipitation $(\mathrm{mm})$ and mean annual air temperature $\left(\mathrm{C}^{\circ}\right)$.

Figure 4. Number of soil profiles under either deciduous, pine or spruce dominated forest grouped according to intervals of soil $\mathrm{C}$ stock given in $\mathrm{kg} \mathrm{C} \mathrm{m}^{-2}$. 


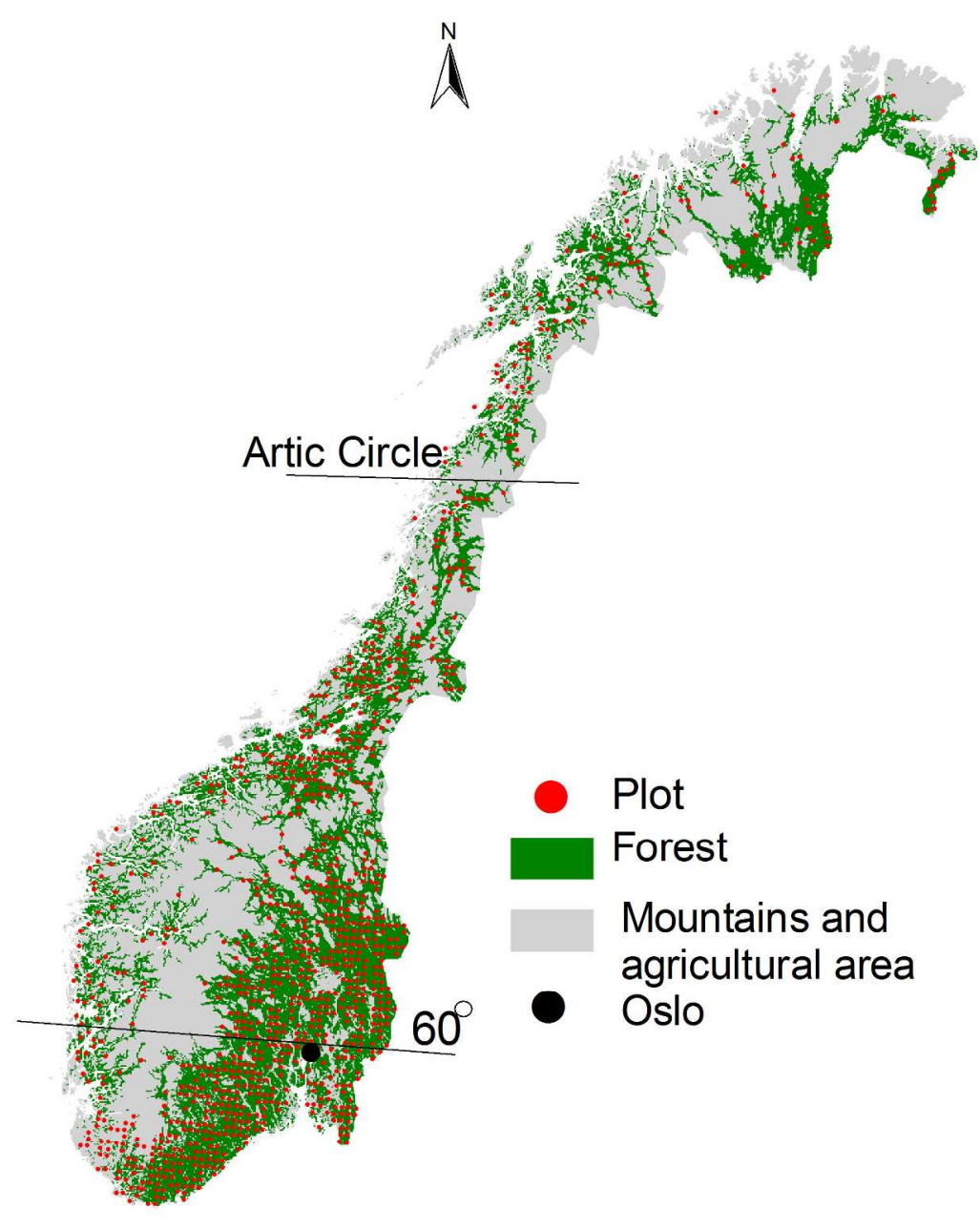

Map of Norway showing forested areas and the grid plots where the forest soils were described and sampled.

$828 \times 1173 \mathrm{~mm}$ (72 x 72 DPI) 

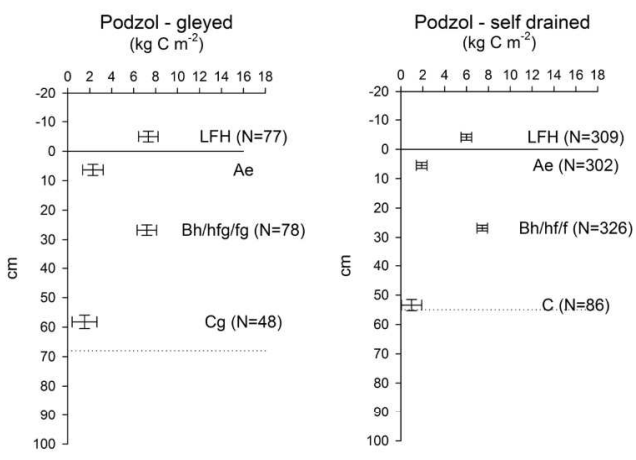

Eluviated Dystric Brunisols

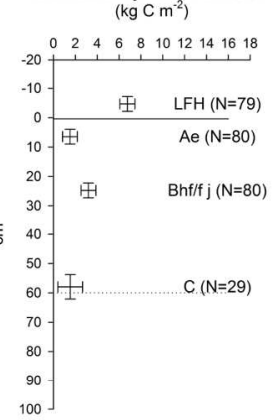

Brunisol - gleyed $\left(\mathrm{kg} \mathrm{C} \mathrm{m}^{-2}\right.$ )

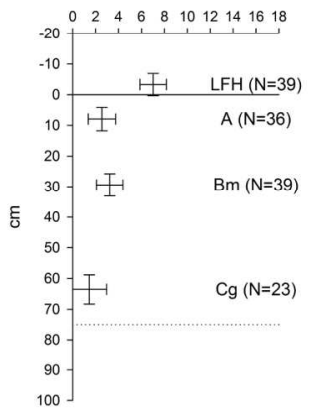

Brunisol - self drained $\left(\mathrm{kg} \mathrm{C} \mathrm{m}^{-2}\right)$

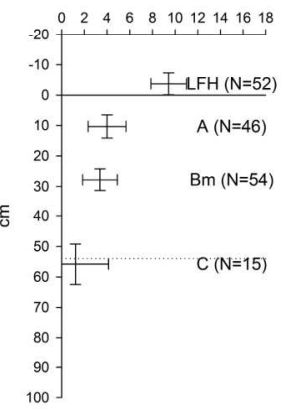

Regosols ( $\mathrm{kg} \mathrm{C} \mathrm{m}^{-2}$ )

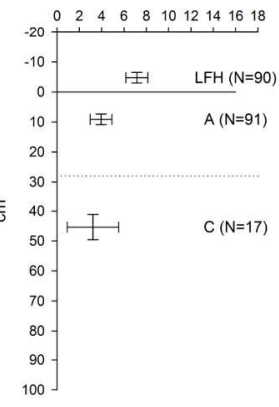

Gleysols

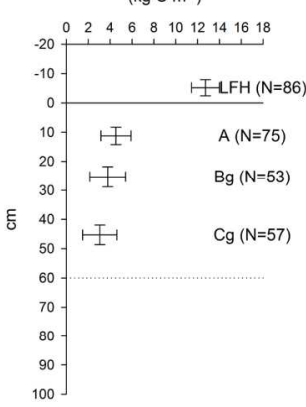

Organic - folisols $\left(\mathrm{kg} \mathrm{C} \mathrm{m}^{-2}\right)$
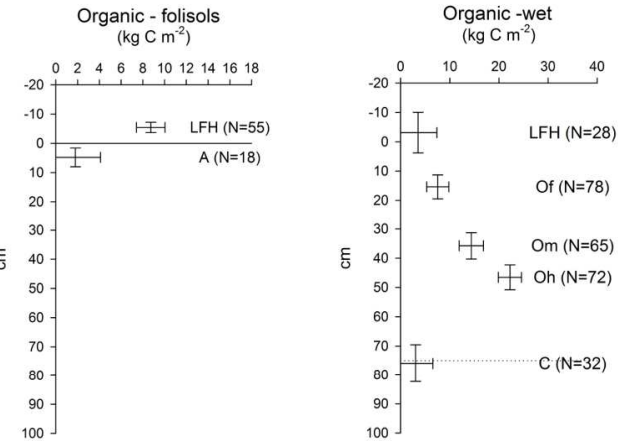

Carbon stock distribution by master horizon and dominant soil classification. Error bars confidence limit, given as $95 \%$ of the least significant mean for the horizon thickness and C stocks. The full line indicates the mineral soil surface; the dotted line indicates the average depth of the soil profiles 

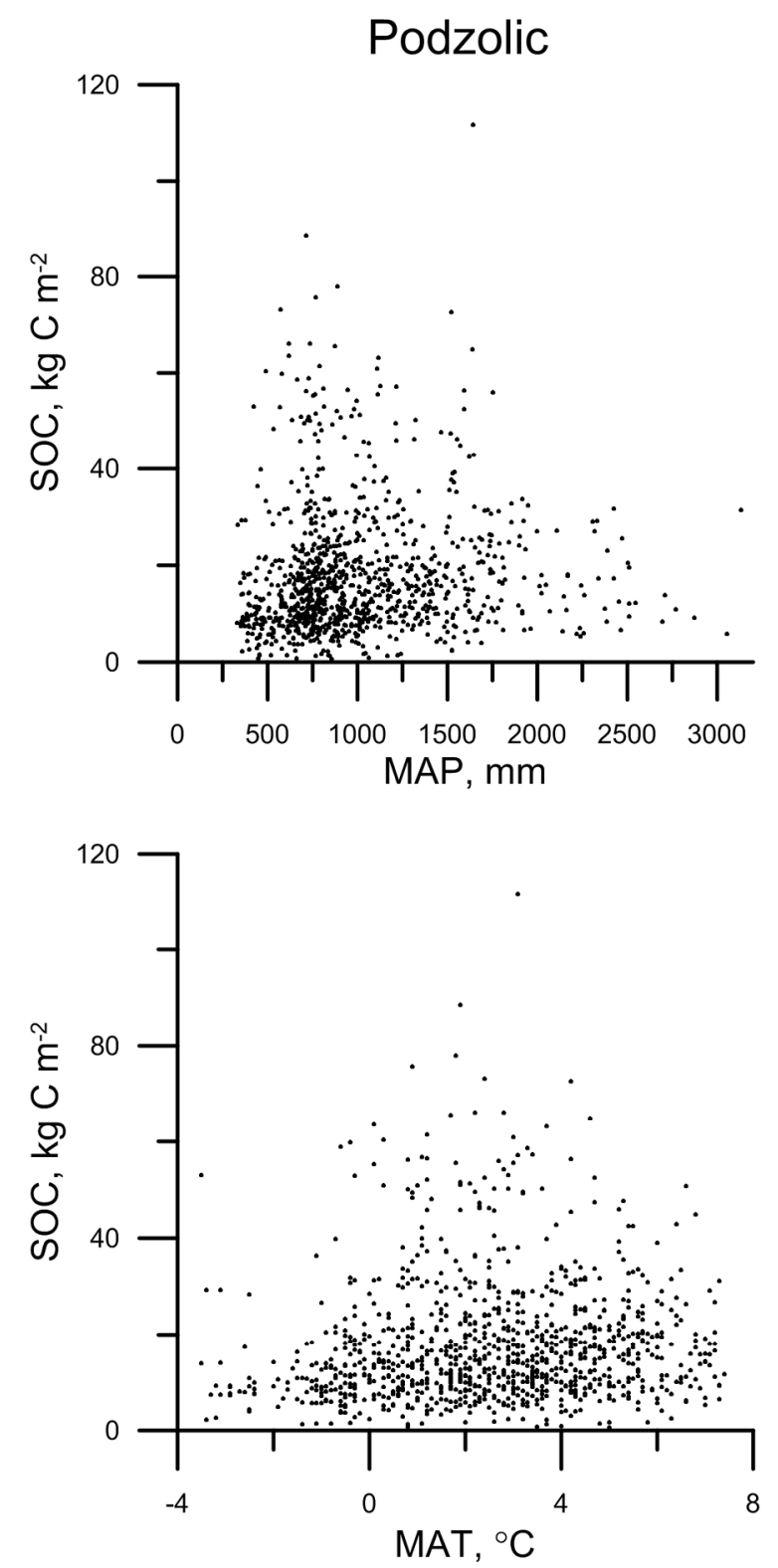

Total carbon stocks of 488 in Norwegian Podzolic forest soils plotted against mean annual precipitation (mm) and mean annual air temperature $\left(\mathrm{C}^{0}\right)$. $97 \times 206 \mathrm{~mm}(299 \times 299$ DPI $)$ 


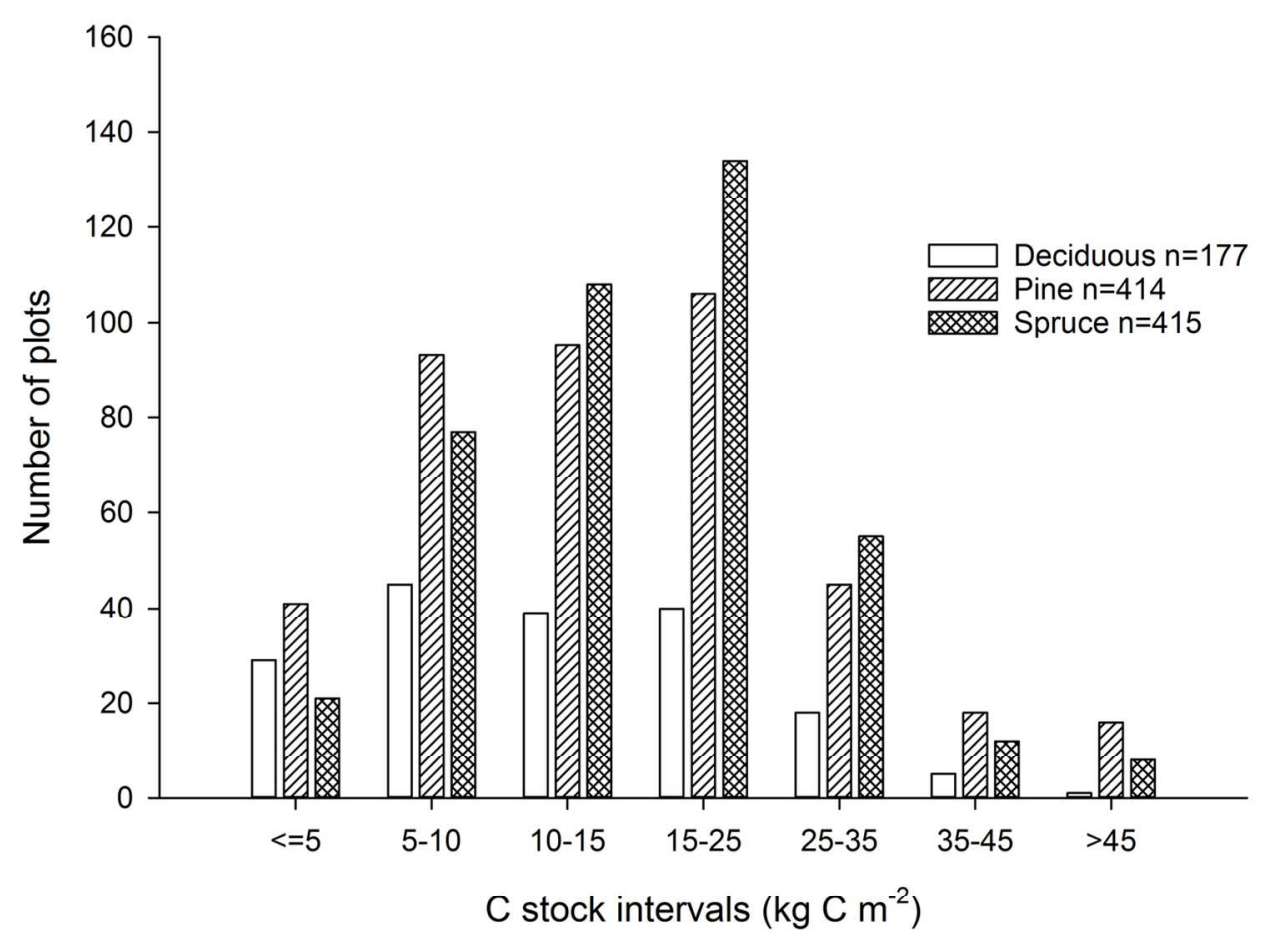

Number of soil profiles under either deciduous, pine or spruce dominated forest grouped according to intervals of soil $\mathrm{C}$ stock given in $\mathrm{kg} \mathrm{C} \mathrm{m-2.}$ $130 \times 111 \mathrm{~mm}(300 \times 300 \mathrm{DPI})$ 